Vertical Distribution of

Velocity and

Suspended Sediment

Middle Rio Grande

New Mexico

GEOLOGICAL SURVEY PROFESSIONAL PAPER 462-B 
Vertical Distribution of

Velocity and

Suspended Sediment

Middle Rio Grande

New Mexico

By CARL F. NORDIN, JR., and GEORGE R. DEMPSTER, JR.

SEDIMENT TRANSPORT IN ALLUVIAL CHANNELS

GEOLOGICAL SURVEY PROFESSIONAL PAPER 462-B

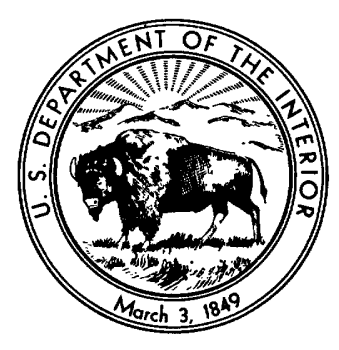

UNITED STATES GOVERNMENT PRINTING OFFICE, WASHINGTON : 1963 


\section{UNITED STATES DEPARTMENT OF THE INTERIOR \\ STEWART L. UDALL, Secretary \\ GEOLOGIGAL SURVEY \\ Thomas B. Nolan, Director}

For sale by the Superintendent of Documents, U.S. Government Printing Office Washington, D.C., 20402 


\section{CONTENTS}

Abstract.. Page|r
Introduction.
Purpose and scope.
Acknowledgments.

\section{ILLUSTRATIONS}

Frgure 1. Location and sketch map.

2. Definition sketch

3. Variation of velocity with depth

4. Variation of $k$ with concentration

5. Variation of $k$ with $C / \sqrt{g}$

6. Bar-resistance curve, Bernalillo and Socorro

7. Bar-resistance curve, Bernalillo, 1952

8. Variation of concentration with $(D-y) / y$, Bernalillo

9. Variation of concentration with $(D-y) / y$, Socorro

10. Variation of $Z_{1}$ with $Z$ and $Z_{\mathrm{k}}$

11. Size distribution of bed material

12. Variation of $Z_{1}$ and fall velocity

13. Variation of $k$ and $\beta$

15. Variation of fall velocity with concentration

16. Comparison of computed $Z$ values

TABLES

TABLE 1. Velocity distribution

2. Suspended-sediment distribution...

3. Basic data.

5. Computed parameters data and computed parameters for the average of 13 cross sections through a $16,000-$ foot reach, Rio Grande near Bernalillo, N. Mex 


\section{SYMBOLS}

\begin{tabular}{|c|c|}
\hline Symbols & Reference distance above the bed \\
\hline & $\begin{array}{l}\text { Reterence distance above the bed } \\
\text { Concentration of suspended sediment }\end{array}$ \\
\hline$C / \sqrt{g}$ & Dimensionless Chezy coefficient \\
\hline$C_{1}$ & . 0 \\
\hline$C_{r}$ & coefficient of discharge \\
\hline$d_{35}$ & Particle size for which 35 percent of the bed material by weight is finer, as determined by sieve analysis..... $\mathrm{mm}$ \\
\hline$d_{50}$ & article size for which 50 percent of the bed material by weight is finer \\
\hline$d_{65}$ & Particle size for which 65 percent of the bed material by weight is finer \\
\hline$d y$ & Increment of distance above stream bed. \\
\hline$D$ & Depth of flow at a vertical \\
\hline $\bar{D}$ & Mean depth of flow in a cross section \\
\hline & Acceleration of gravity \\
\hline & An exponent \\
\hline & An exponent \\
\hline & The coefficient of turbulent exchange \\
\hline$K_{8}$ & A length parameter \\
\hline$m$ & Slope of semilogarithmic graph of velocity versus depth for a single vertical \\
\hline$m$ & verage slope of velocity versus depth for all verticals in a cross section \\
\hline & diment \\
\hline$P_{w}$ & 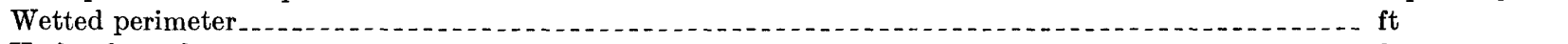 \\
\hline$R$ & lius \\
\hline$R^{\prime}$ & IS with respect to the sand grain \\
\hline$R^{\prime \prime}$ & h respect to dunes and bars \\
\hline$S$ & face slope \\
\hline$S_{e}$ & Energy slope \\
\hline$\underline{V}$ & Velocity at a point \\
\hline $\bar{V}$ & Mean velocity \\
\hline$V *$ & Shear velocity \\
\hline & A correction factor for transition from smooth to rough boundary \\
\hline & Distance above stream bed \\
\hline$Z$ & exponent for vertical distribution of suspended sediment using $k=0.4$ \\
\hline$Z_{1}$ & al measure of the actual distribution of suspended sediment \\
\hline$Z_{k}$ & Computed exponent for vertical distribution of suspended sediment using $k=(2.3 / m) V_{*} \ldots \ldots$ \\
\hline & tionality between $\epsilon_{s}$ and $\epsilon_{m}$ \\
\hline & - \\
\hline$\delta^{\prime}$ & iblayer \\
\hline$\Delta$ &  \\
\hline$\epsilon_{m}$ & fficient \\
\hline$\epsilon_{s}$ & coefficient \\
\hline & scosity \\
\hline$\rho_{f}$ & Density of fluid \\
\hline $\begin{array}{l}\rho_{s} \\
\tau_{0}\end{array}$ & Density of sediment \\
\hline & Tractive force on the bed \\
\hline$\psi^{\prime}$ & A flow intensity parameter \\
\hline & relocity of sediment $\mathrm{p}$ \\
\hline
\end{tabular}


SEDIMENT TRANSPORT IN ALLUVIAL CHANNELS

\title{
VERTIGAL DISTRIBUTION OF VELOGITY AND SUSPENDED SEDIMENT, MIDDLE RIO GRANDE, NEW MEXICO
}

\author{
By Carl F. Nordin, Jr. and George R. Dempster, Jr.
}

\begin{abstract}
Samples of suspended sediment and measurements of velocity at 3 to 5 points in a vertical are used to define vertical sediment concentration and velocity profiles for cross sections in reaches of the Rio Grande near Bernalillo and Socorro, and of the Rio Puerco near Bernardo, N. Mex.

Velocity profiles show the velocity to vary logarithmically with depth. The coefficient of turbulent exchange, $k$, is found to decrease systematically for the transition zone and upper regime flow. For lower regime flow, $k$ varies from about 0.4 to 1.2 , indicating three-dimensional flow effects.

Assuming a conventional logarithmic velocity equation to be applicable, it is found that the range of values of $K_{s}$, the height of the representative roughness element, is dependent upon the condition of the channel bed. The ratio of maximum to minimum $K_{s}$ is about 20,000 for lower regime flow, 40 for transition and upper regime flow, and 4 for flow over a clay-armored bed. However, the relation of the average $K_{s}$ value to the average representative bed-material size for each of the reaches is about constant, and is approximately 400 times greater than $d_{65}$, the size of bed material for which 65 percent by weight is finer.

The Einstein-Barbarossa bar-resistance curve is shown to describe frictional losses for individual cross sections of the Bernalillo and Socorro reaches with reasonable accuracy. Twenty of the 23 computed values of mean velocity are within 25 percent of the measured values. When an average cross section is used for the Bernalillo reach, the computed mean velocities are within 15 percent of the measured values.

Suspended sediment is more uniformly distributed through a vertical than predicted by conventional theory. The measured exponent of the sediment distribution, $Z_{1}$, varies with about the 0.55 power of the fall velocity. The fall velocity is reduced appreciably by the presence of ingh concentrations of suspended fine material.

The ratio of the sediment transfer coefficient to the momentum transfer coefficient, $\beta$, appears to be a direct function of particle size and bed configuration. For a given particle size the highest values of $\beta$ are associated with upper regime flow, while for lower regime flow, $\beta$ values are close to unity.
\end{abstract}

\section{INTRODUCTION}

\section{PURPOSE AND SCOPE}

The purpose of this report is to present measured values of vertical velocity and suspended-sediment concentration distributions, and to compare the measured values with values computed from theoretical considerations. Some of the variables in the distribution equations are analysed. In addition, one method of estimating mean velocity is discussed.

Data are presented for 23 observations in reaches of the Rio Grande near Bernalillo and the Rio Grande near Socorro, N. Mex. Limited data for the Rio Puerco, a tributary to the Rio Grande, also are included to indicate some of the effects of high suspendedsediment concentrations. Data for the Rio Grande near Bernalillo and near Socorro were collected during the period 1953-54 as part of a cooperative program between the U.S. Geological Survey and the U.S. Bureau of Reclamation to study sediment transport in the Middle Rio Grande, N. Mex.

This report is one of several utilizing available data for the Middle Rio Grande basin for studies of sedimenttransport parameters in sand-bed streams.

\section{ACKNOWLFDGMFNTS}

This report was written under the supervision of J. M. Stow, district chemist, and J. K. Culbertson, hydraulic engineer, Quality of Water Branch, Albuquerque District, N. Mex.

Appreciation is expressed to A. A. Fischback, Jr., district engineer, Surface Water Branch, Oklahoma City, Okla., and others for their cooperation.

\section{DESCRIPTION OF REACHES}

Velocity and suspended-sediment concentration distributions were measured in two reaches of the Rio Grande: Rio Grande near Bernalillo, and Rio Grande near Socorro, N. Mex. In addition, several observations were obtained for a single cross section on the Rio Puerco near Bernardo. A location and sketch map of the reaches is shown in figure 1.

The Bernalillo reach is located approximately 3 miles southwest of Bernalillo and 9 miles downstream from the Jemez River. The right bank at the upstream portion of the reach is a high bluff composed of calcareous sandstone. The bluff veers away from the 

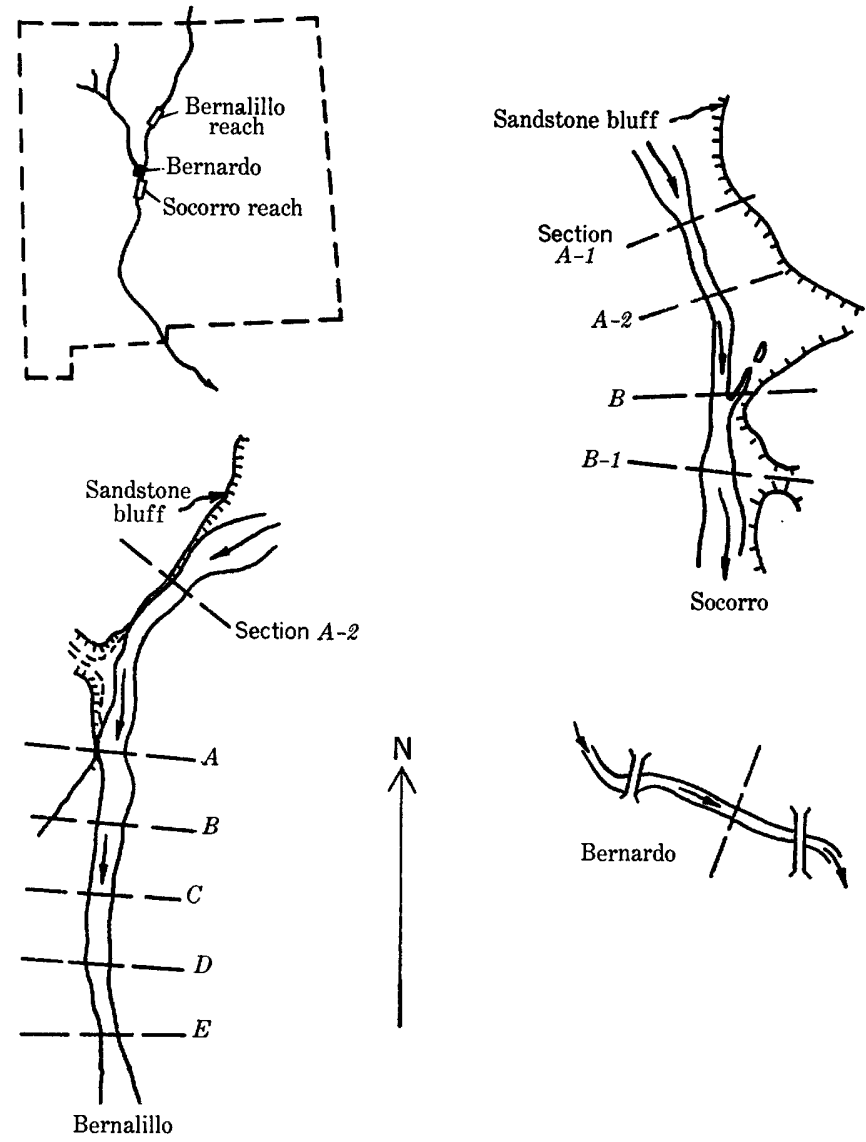

Figure 1.-Location and sketch maps of Rio Grande near Bernalillo, Rio Grande near Socorro, and Rio Puerco near Bernardo, N. Mex.

river about 200 yards downstream from the uppermost cross section. Throughout the rest of the reach, both banks consist of a mixture of sand, silt, and clay, and are partially stabilized by vegetation. The reach is laterally unconfined except at section $\mathrm{A}-2$, which is the site of a U.S. Geological Survey gaging station. The reach is about 7,000 feet in length.

The Socorro reach is approximately 28 miles downstream from the mouth of the Rio Puerco and a quarter of a mile northeast of Socorro. Both banks of the reach consist of silty clay and are partially stabilized by vegetation. The reach diverges somewhat and is about 4,000 feet in length.

The Bernardo reach is located about 1 mile southwest of Bernardo and 3 miles upstream from the mouth of the Rio Puerco. This is the site of a U.S. Geological Survey gaging station. Both banks consist of silty clay and are stabilized by vegetation. The cross section is located about midway of a slightly converging reach approximately 630 feet in length immediately downstream from the gaging station. The reach has a sand bed, but for the several observations presented, the bed was armored with a layer of clay and silt 0.1-0.6 foot thick.

\section{MEASURED DATA}

Basic data for 26 observations of velocities and suspended-sediment concentrations are shown in tables 1 and 2.

Velocities were measured with a Price current meter and samples of suspended sediment were collected at points in the vertical with a US $\mathrm{P}-46$ sampler or a modified DH-48 hand sampler. Suspended-sediment samples were analyzed for particle-size distribution by the pipette-visual accumulation tube method. Vertical distributions of velocity and suspended sediment were defined at approximate equal centroids of flow at each cross section. The number of centroids varied from 2 to 5 , except in one case, where 15 velocity profiles were obtained. The number of points in a vertical varied from 3 to 5 and were obtained at approximate equal $(D-y) / y$ horizons. Concentrations shown in table 2 were determined from a composite of samples for the indicated horizons. Figure 2 is a

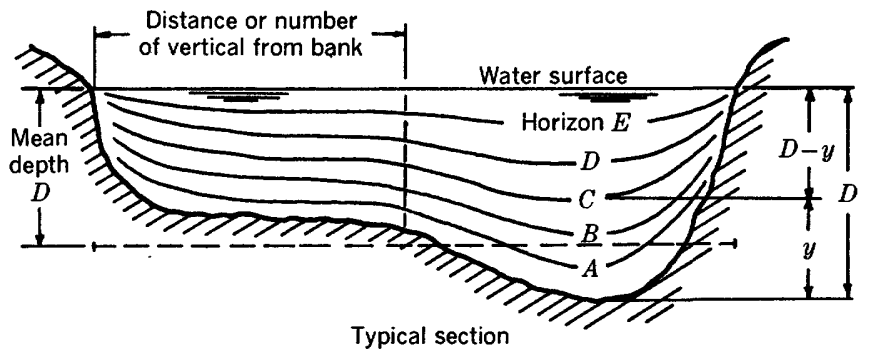

FIgURE 2.-Deflnition sketch of equal $(D-y) / y$ horizons, any cross section.

definition sketch showing equal $(D-y) / y$ horizons in any cross section. Verticals were numbered consecutively from the right bank.

Obtained concurrently with velocity and suspendedsediment samples were water discharge, width, mean depth, mean velocity, water temperature, water-surface slope, and bed-material samples. These data are shown in table 3.

Water-surface slopes for the Bernalillo and Socorro reaches were determined as the slope of the line fitted by method of least squares through the plotted watersurface profile. Particle-size distributions of bedmaterial samples were determined by seiving. Values of $d_{65}, d_{50}$, and $d_{35}$, where the subscript denotes the percent finer by weight, were read from a logarithmic probability plot of size distribution. These data were furnished by the United States Bureau of Reclamation.

Water-surface slopes in the Bernardo reach were determined by dividing the difference in water-surface elevation between two cross sections by the distance between the two sections.

For the data herein, the width-depth ratio is large and it is assumed $R=D$ for a cross section. For 
practical purposes, the flow is considered uniform and $S_{e}=S$; also bank friction is considered to be negligible.

\section{GENERAL APPROACH}

The equation for suspended-sediment discharge per unit width for two-dimensional flow is given by

where

$$
q_{s}=\gamma \int_{a}^{D} V_{y} c_{y} d y
$$

$$
\begin{aligned}
q_{*} & =\text { the transport rate of suspended sediment between } \\
& \quad \text { the depths } a \text { and } D \\
\gamma & =\text { the average unit weight of the water-sediment mixture } \\
a & =\text { reference depth } \\
D & =\text { flow depth } \\
V_{y} & =\text { flow velocity at depth } y \\
c_{y} & =\text { concentration at depth } y
\end{aligned}
$$

In order to integrate equation $1, V_{y}$ and $c_{y}$ must be expressed as functions of $y$.

The velocity distribution for two-dimensional openchannel flow over a rough boundary as presented by Keulegan (1938) is

$$
\frac{V_{y}}{V_{*}}=\frac{2.3}{k} \log _{10} \frac{y}{K_{*}}+C_{1}
$$

where

$$
\begin{aligned}
V_{*} & =\sqrt{g R S_{6}}=\text { shear velocity } \\
k & =\text { von Karman coefficient of turbulent exchange } \\
y & =\text { distance above bed } \\
K_{2} & =\text { a length parameter } \\
C_{1} & =\text { a constant } \\
g & =\text { acceleration due to gravity } \\
R & =\text { hydraulic radius } \\
S_{0} & =\text { energy gradient }
\end{aligned}
$$

Equation 2 is not generally applicable for flow over an alluvial boundary, but in this report the equation will be used throughout as a basis for comparison with measured velocity distributions.

The equation for sediment suspension was introduced by O'Brien (1933) as

$$
\omega c=\epsilon, \frac{d c}{d y}
$$

where

$$
\begin{aligned}
\omega & =\text { the fall velocity of the sediment particle. } \\
c & =\text { concentration of suspended sediment. } \\
\epsilon_{8} \frac{d c}{d y} & =\text { rate of upward transfer of suspended sediment } \\
& \text { from turbulent exchange. }
\end{aligned}
$$

Rouse (1937) showed that equation 3 could be integrated to yield an equation for the distribution of the relative concentration of the suspended sediment as

where

$$
\frac{c_{y}}{c_{a}}=\left(\frac{D-y}{y} \cdot \frac{a}{D-a}\right)^{z}
$$

$c_{y}=$ concentration of a grain size at depth $y$ above bed. $c_{a}=$ concentration of a grain size at reference level $a$ above bed.
$Z=$ theoretical exponent of the distribution equation given by

$$
Z=\frac{\omega}{\beta k V_{*}}
$$

where

$\beta=$ ratio of the transfer coefficient for sediment $\left(\epsilon_{s}\right)$ to the momentum transfer coefficient $\left(\epsilon_{m}\right)$.

In the derivation of equations 4 and 5 , it was assumed that

$$
\begin{aligned}
\epsilon S & =\epsilon_{m} \\
\beta & =\frac{\epsilon_{\mathrm{e}}}{\epsilon_{m}}=1
\end{aligned}
$$

and

$$
k=0.4
$$

The general forms of equations 2 and 4 are well established, but the solution to the suspended-sediment transport rate is not completely formulated. Neither $k$ nor $K_{s}$ is constant and the exponent $Z$ given by equation 5 does not agree with $Z_{1}$, the exponent that fits the measured data.

Equation 2 may be integrated over a representative vertical to obtain mean velocity. Keulegan (1938) has shown that the mean velocity for open-channel flow over a wholly rough surface of a rigid boundary may be expressed as

$$
\frac{\bar{V}}{V_{*}}=6.25+5.75 \log \frac{R}{K_{8}}
$$

where

$$
\bar{\nabla}=\text { mean velocity. }
$$

The constant 6.25 is a mean value, and varies with several factors such as effect of the shape of section, the free surface, and nonuniform distribution of the tractive forces at the boundary. For sand-grain roughness only, such as flow over a flat sand bed, $K_{3}$ assumes the value of a representative grain size or an equivalent height of the roughness elements. For natural river sediments, Einstein (1950) used the value of $d_{65}$ for $K_{s}$. In many natural channels with flow over an alluvial bed, $K_{s}$ is greater than $d_{65}$ owing to the presence of dunes and bars on the bed.

The quantitative relation between dune characteristics and the roughness parameter $K_{s}$ is not known. Flume studies with rigid boundaries (Sayre and Albertson, 1961) have shown that roughness conditions are dependent upon the relative size and spacing of the roughness elements and that the overall boundary roughness can be expressed as one parameter in the velocity equation. If the relative size and spacing of dunes and bars in a natural channel could be measured, a more complete evaluation of $K_{s}$ could be made. Sonic-sounding equipment offers possibilities in this field. Sonic-sounding equipment has been used in the Mississippi River (Carey and Keller, 1957) and in the 
laboratory (Richardson, Simons, and Posakony, 1961), but the information obtained is more qualitative than quantitative and thus is not subject to a rigorous mathematical analysis.

Several flume and field studies present qualitative information on the relations between resistance coefficients and bed configuration. The forms of bed roughness observed in flume studies using $0.28 \mathrm{~mm}$ and 0.45 $\mathrm{mm}$ median-diameter sand have been described in detail by Simons and Richardson (1961). They indicate that flow may be classified into lower regime and upper regime with a transition zone between, and that both resistance and sediment transport are intimately related to flow regime. The lower and upper flow regime classification is based upon magnitude of resistance to flow, bed and water surface configuration, and mode and magnitude of sediment transport. The bed roughness for lower regime flow is ripples or dunes or both, the resistance to flow is large, and the bed material transport rate is low. For upper regime flow, the bed is relatively plane, standing waves or antidunes may be present on the water surface, the flow resistance is low, and the rate of transport of bed material is relatively high. These general regimes of flow are applicable to natural streams. Culbertson and Dawdy (1963) and Dawdy (1961) have shown that these different regimes of flow occur in the Rio Grande and in many other sand-bed streams.

\section{VELOCITY DISTRIBUTION}

Typical velocity profiles (fig. 3 ) show that the velocity distributions fit a logarithmic law. It is noted that lateral variation of velocity distribution and depth occur in the cross section. For practical purposes, mean values of velocity and depth are used.

Values of the Von Karman coefficient of turbulent exchange $(k)$ can be computed from a form of equation 2 as

$$
\frac{V_{1}-V_{2}}{\log y_{1}-\log y_{2}}=\frac{2.3}{k} V_{*}=m
$$

where $V_{1}$ and $V_{2}$ are the velocities at depth $y_{1}$ and $y_{2}$, respectively, and $m$ is the slope of the velocity profile in feet per second change per log cycle of depth; thus

$$
k=\frac{2.3}{m} V_{*}
$$

The average $k$ for a cross section was computed using $\bar{m}$ and $V_{*}$ where $\bar{m}$ is the average of the individual $m$ values of all the verticals in a cross section and $V_{*}=\sqrt{g \bar{D} S}$. The values of $\bar{m}$ and $k$ are shown in table 4. Values of $k$ vary widely, ranging from 0.15 to 1.20. For the Socorro reach and Bernardo cross section, the values of $k$ appear to vary systematically

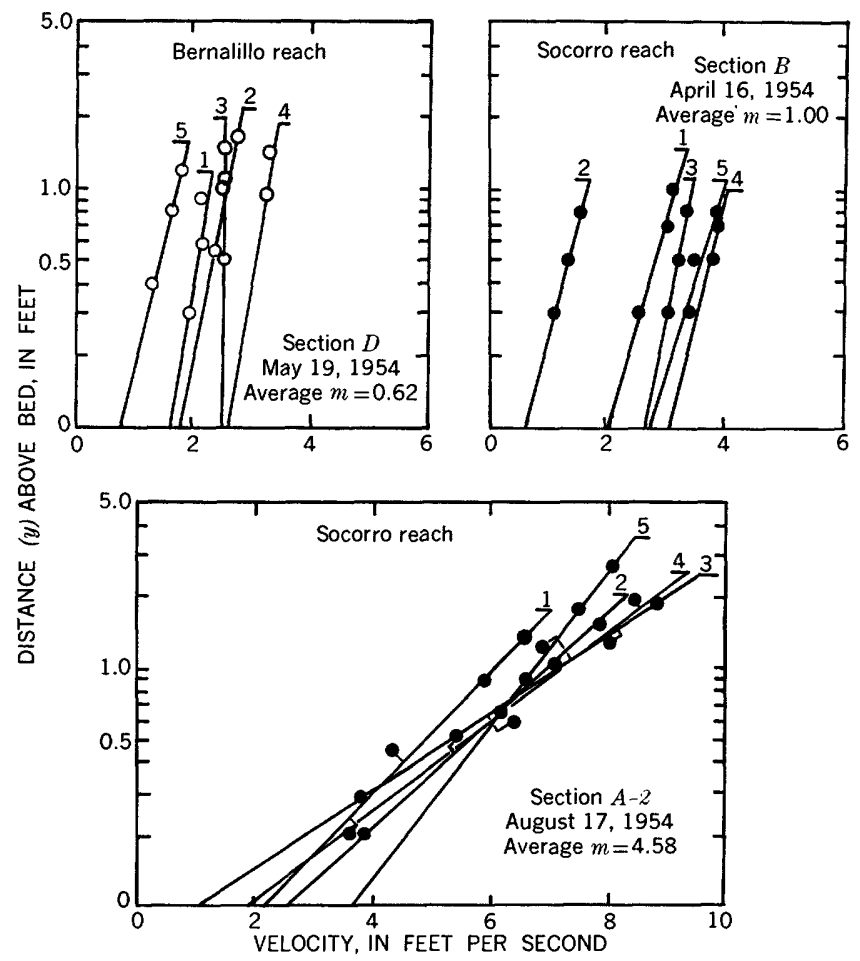

Figure 3.-Variation of velocity with depth, Rio Grande near Bernalillo and Socorro.

and are generally less than 0.4. Conversely, the Bernalillo values appear to be random and gènerally are greater than 0.4 , varying from 0.35 to 1.2 .

Flume and river measurements show that the $k$ for sediment-laden flow generally varies from the 0.4 that was determined by Nikuradse for pipe flow with clear water. Vanoni and Brooks (1957) and Ismail (1951) suggested that sediment dampens the turbulence and reduces the momentum transfer. In effect, this results in a reduction of $k$. Einstein and Chien (1955) measured the reduction of $k$ by the amount of turbulent energy spent in supporting the sediment in suspension. The rate at which frictional energy is spent per unit weight of fluid per unit time in supporting the sediment in suspension was expressed as

$$
\sum \frac{C_{8} \omega}{\bar{V} S_{e}} \frac{\rho_{s}-\rho_{f}}{\rho_{g}}
$$

where $c_{s}=$ average concentration by weight of a given particle size, and $\Sigma$ signifies the summation of the concentrations and fall velocities of all the particle sizes present. Values of $k$ plotted versus equation 9 in figure 4 show wide scatter. Socorro and Bernardo data generally follow the predicted trend, while the Bernalillo data show no definite trend. Dashed lines on the figure indicate the approximate scatter of points from which the relation was defined by Einstein and Chien. About half of the 26 points fall within or close 


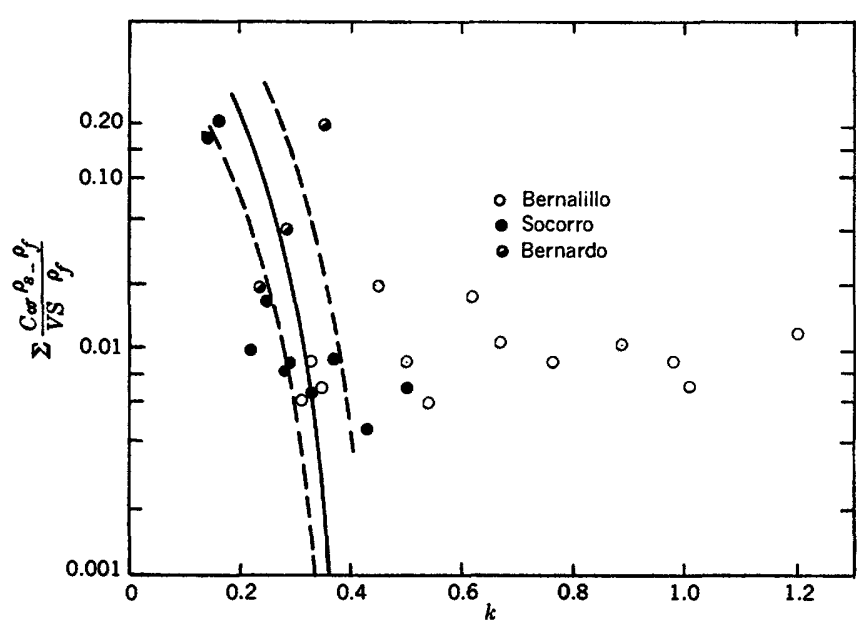

Fiquar 4.-Variation of $k$ with concentration, Rio Grande near Bernalillo, Socorro, and Rio Puerco near Bernardo. Dashed lines indicate approximate envelope of points used to define the relation. From Einstein and Chien, 1955.

to the envelope. Values of equation 9 for the data herein are shown in table 4. That portion of the summation for particle size less than $0.062 \mathrm{~mm}$ was obtained by assuming all material was in a size range of $0.002-0.062 \mathrm{~mm}$ and then using a fall velocity based on the geometric mean size of this class.

Chien (1954) suggested that $k$ may change with roughness if the height of the roughness elements are comparable to the mean depth of flow. Field observations in the Bernalillo reach show that the height of dunes in fully developed lower regime flow is often equal to or greater than one-half the mean depth. Under such conditions, extreme lateral variations in a cross section may occur and the flow may exhibit three dimensional characteristics.

Figure 5 shows the variation of $k$ with $\bar{V} / V_{*}=C / \sqrt{g}$. In this figure there is no quantitative measure of the dune height, but a qualitative measure of bed configuration based on the three regimes of flow may be shown

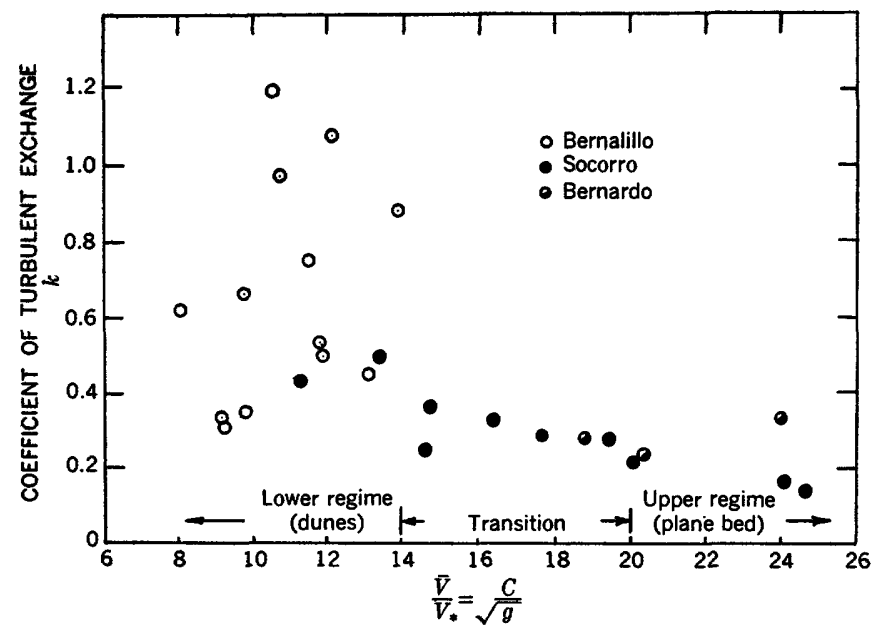

FiquRE 5.-Variation of $k$ with $C / \sqrt{g}$.
The $C / \sqrt{g}$ values indicated on the figure for the various flow regimes are based on field observations where bed configuration was verified by probing. These $C / \sqrt{g}$ values are in close agreement with those reported by Simons and Richardson (1961). The figure clearly indicates that extreme variations of $k$ occur for flow over a dune bed.

Sayre and Albertson (1961) reported $k$ values ranging from 0.34 to 2.77 as determined by the velocity-profile method (equation 8) for clear-water flow with isolated roughness baffles. However, from the slope of the average lines drawn through plots of $V / V_{*}$ versus relative roughness, they determined that the average or "integrated" $k$ was in fact a constant, with a value of 0.38 . They attribute the wide variation in $k$ values determined from the velocity-profile method to threedimensional flow effects and large scale vortices, and they conclude that equation 8 is not adequate to define $k$ where such flow conditions exist. The wide range of $k$ values for flow over a dune bed shown in figure 5 probably reflects the same effects that were reported by Sayre and Albertson.

The decreasing value of $k$ with increasing $C / \sqrt{g}$ for transition and upper regime flow may or may not be related to changing roughness. Because sediment transport generally increases with an increase in $C / \sqrt{g}$, the decrease of $k$ may be attributed, in part, to a concentration effect.

Although $k$ may not be adequately defined for flow over a dune bed, the velocity for such flow is still proportional to the logarithm of the depth. If a form of equation 2 applies, and if $k$ attains a near-constant value of about 0.4 , the proportionality factor between $V$ and $\log y$ does not equal the shear velocity $V_{*}$, but must assume a much smaller value. From equation 7 , the proportionality factor is approximately equal to $\bar{m} / 5.75$. Einstein (1950) introduced a shear velocity with respect to the grain roughness, $V_{*}{ }^{\prime}$, which is less than $V_{*}$. For the data in table 4, the factor of proportionality between velocity and the logarithm of the depth, $m / 5.75$, is considerably less than Einstein's $V_{*}{ }^{\prime}$.

Regardless of the value of the proportionality factor relating velocity to the logarithm of the depth, if equation 2 applies with $C_{1}=8.5$ as given by Keulegan, the value of $K_{s}$ may be determined from a plot of $V$ versus $\log y$ by extrapolating the line through the plotted point to intercept the ordinate at zero velocity. This follows from equation 2 , where the velocity must equal zero when the logarithm of $30.2 y / K_{s}$ equals zero.

Values of $K_{s}$ for each cross section were determined for the data in table 4 by two methods: first, as the average of the $K_{s}$ values for the individual verticals read from the $V$ versus log $y$ plots extrapolated to intercept the ordinate at zero velocity; second, by plot- 
ting mean velocity $\vec{V}$ at $y=0.4 \bar{D}$ on semilog paper, and extending a line with slope $\bar{m}$ to intercept the ordinate at zero velocity. For any given cross section, the values of $K_{s}$ computed by the two methods vary appreciably but are of the same order of magnitude; therefore, the two values were averaged to obtain the $K_{s}$ shown in table 4.

The values of $\bar{m}$ and $K_{s}$ in table 4 were defined from a limited number of verticals, and thus may not describe accurately the average velocity distribution in a cross section. Even so, for a given reach, the range of values of $K_{s}$ and the ratio of the average $K_{s}$ to the average $d_{65}$ should provide an indication of bed-configuration effects on velocity distributions. These data are shown in the table below.

For Bernalillo, where flow was in lower regime, $K_{s}$ varies by a factor of about 20,000 . Flow in the Socorro reach was mostly in transition or upper regime, and the ratio of maximum to minimum $K_{s}$ is 48 . At Bernardo the bed was armored with clay, the flow was comparable to flow over a rigid boundary, and $K_{s}$ varies by a factor of 4 . These values indicate clearly the extreme influence which bed configuration has on velocity distributions.

It is significant that the mean value of $K_{s}$ is much greater than $d_{65}$, even for the clay-armored bed of the Rio Puerco, which was relatively free of irregularities. The values of the ratio of the mean $K_{s}$ to $d_{65}$ are remarkably constant, considering the wide differences in bed conditions for the three reaches. That such similarities should be fortuitous seems unlikely. The data tabulated below suggest that although the bed condition dictates the range of $K_{s}$ values, it is the size of the bedmaterial and not the bed configuration which determines the mean $K_{s}$. For the range of conditions examined, the mean $K_{s}$ is about 400 times as great as $d_{65}$.

In the foregoing discussion, no consideration was given to the correction factor for the transition from smooth to rough boundaries (Rouse, 1937). Inclusion of the factor could alter the values of $K_{s}$ by as much as 20 percent.

\section{MEAN VELOCITY}

Where the relative effects of bed configuration on flow resistance are minor, mean velocity may be predicted with reasonable accuracy by using empirical formulas of the Manning or Chezy type with coefficients based upon a grain-size roughness.

Two empirical formulas which attempt to predict the relation between bed configuration and flow resistance have been proposed (Liu and Hwang, 1959; Einstein and Barbarossa, 1952).

\begin{tabular}{|c|c|c|c|c|c|c|c|}
\hline \multicolumn{8}{|c|}{ Summary of $K_{8}$ values } \\
\hline \multirow[b]{2}{*}{ Reach } & \multicolumn{3}{|c|}{$K_{\varepsilon}$, in $\mathrm{ft}$} & \multirow{2}{*}{$\frac{K_{0} \max }{K_{6} \min }$} & \multirow[b]{2}{*}{$\begin{array}{l}d_{65} \\
\mathrm{ft}\end{array}$} & \multirow{2}{*}{$\frac{\text { Mean } K_{s}}{d_{65}}$} & \multirow[b]{2}{*}{ Bed condition } \\
\hline & $\begin{array}{l}\text { mini- } \\
\text { mum }\end{array}$ & $\begin{array}{l}\operatorname{maxi}- \\
\text { mum }\end{array}$ & mean & & & & \\
\hline $\begin{array}{l}\text { Bernalillo..... } \\
\text { Socorro....... }\end{array}$ & $\begin{array}{l}0.000086 \\
.020\end{array}$ & $\begin{array}{r}1.86 \\
.95\end{array}$ & $\begin{array}{r}0.47 \\
.27\end{array}$ & $\begin{array}{r}22,000 \\
48\end{array}$ & $\begin{array}{r}0.00121 \\
.00072\end{array}$ & $\begin{array}{l}388 \\
375\end{array}$ & Dunes. \\
\hline Bernardo..... & .03 & .11 & .078 & 4 & .0002 & 390 & clay-armored. \\
\hline
\end{tabular}

Liu and Hwang presented a formula of the Chezy type

$$
\bar{V}=C_{r} R^{i} S^{i}
$$

where $C_{r}$ and the exponents, $i$ and $j$, are functions of bed configuration and particle size of the bed material. It has been shown that Liu's criterion for the prediction of bed configuration is not applicable to the Rio Grande data (Culbertson and Nordin, 1960).

Einstein and Barbarossa (1952) introduced an approach to the determination of flow resistance where the total resistance was divided into two parts, one due to the sand-grain roughness, and the other due to bars, dunes, and the general irregularities of the channel bed. The velocity equation given by Einstein and Barbarossa was

where

$$
\frac{\bar{V}}{V_{*^{\prime}}}=5.75 \log _{10}\left(12.27 \frac{R^{\prime} x}{K_{8}}\right)
$$

$$
\begin{aligned}
& K_{*}=\text { the representative grain roughness } d_{65} . \\
& R^{\prime}=\text { the hydraulic radius with respect to the sand } \\
& \text { grain. } \\
& x=\text { a correction factor for channels which are not } \\
& \text { hydrodynamically rough and is given as a } \\
& \text { function of } \frac{K_{*}}{\delta^{\prime}} \text {. } \\
& \delta^{\prime}=\text { the theoretical thickness of the laminar sub- } \\
& \text { layer, which is equal to } \frac{11.6 \nu}{V_{*}^{\prime}} \cdot \\
& \nu=\text { the kinematic viscosity. }
\end{aligned}
$$

That part of the resistance due to bars and dunes was expressed as a functional relation between the dimensionless resistance factor, $V / V_{*}{ }^{\prime \prime}$, and flow intensity, $\psi^{\prime}$, where $V_{*}^{\prime \prime}=\sqrt{g R^{\prime \prime} S}$, the shear velocity with respect to the dunes and bars, and

$$
\begin{gathered}
\psi^{\prime}=\frac{\rho_{s}-\rho_{f}}{\rho_{f}} \quad \frac{d_{35}}{R^{\prime} S_{\odot}} \\
\rho_{s} \text { and } \rho_{f}=\text { the densities of the sediment and fluid } \\
\text { respectively. } \\
\text { and } d_{35}=\text { representative grain diameter of bed material. }
\end{gathered}
$$

The functional relation of $\bar{V} / V_{*}{ }^{\prime \prime}$ to $\psi^{\prime}$, called the barresistance curve, was defined from average cross sections and representative slopes for reaches in several natural channels. For a given mean depth, slope, and bed material, the mean velocity may be computed by 
trial and error from equations 11 and 12 and several graphs presented by Eimstein. The accuracy with which mean velocity may be predicted depends upon the accuracy with which the $\bar{V} / V_{*}^{\prime \prime}-\psi^{\prime}$ relation expresses frictional losses due to bars, dunes, and other irregularities on the bed for the channel under consideration. Vanoni and Brooks (1957) and Vanoni and others (1961) have discussed the applicability of the bar-resistance curve for flume data and for some limited natural-channel data.

The graphical method presented by Vanoni and Brooks was used to compute values of $\bar{V} / V_{*}{ }^{\prime \prime}$ and $\psi^{\prime}$ for the Bernalillo and Socorro data. These values, listed $\mathrm{m}$ table 4 , are plotted im figure 6 and show reasonable agreement with the predicted relation. Of 23 computed values of mean velocity using the EinsteinBarbarossa approach, 20 are within 25 percent of the measured values. Some scatter on the plot may be attributed to the use of $k=0.4$ in the velocity equation and to the use of data at imdividual cross sections.

From the manner in which the bar-resistance curve was derived, the curve should describe conditions for a reach of a natural unconfined channel. The relations do not necessarily apply to an individual cross section. Vanoni and Brooks (1957) apply data for several cross sections of the Bernalillo reach to the bar-resistance curve. On the basis of the scatter of the points for these imdividual cross sections, they conclude that the 1952 data "do not lend confidence to the bar-resistance curve." Figure 7 shows the 1952 Bernalillo data using average conditions for 13 cross sections through a 16,000 -foot reach. All computed values of mean velocity are within 15 percent of the measured mean

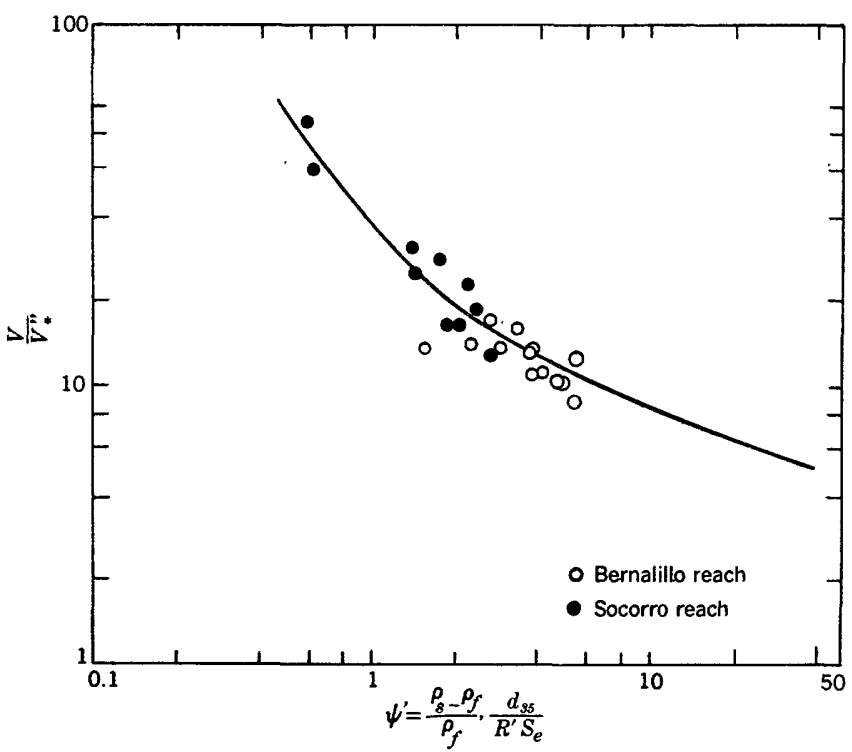

Figure 6.-Einstein-Barbarossa bar-resistance curve for Rio Grande near Bernalillo and near Socorro. Curve from Einstein and Barbarossa, 1952.

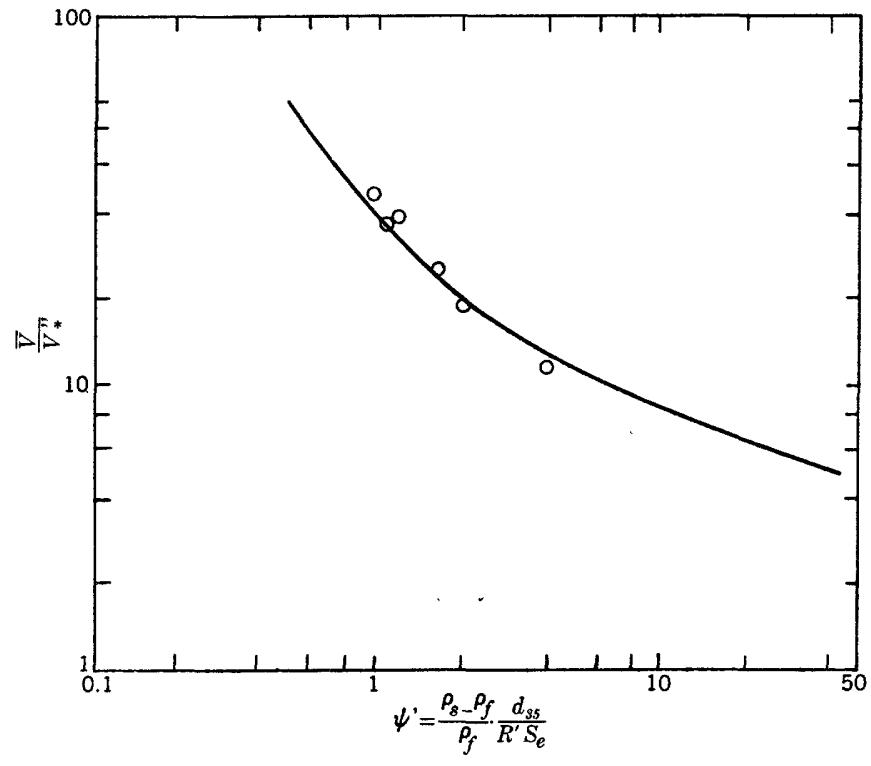

FIGURE 7.-Einstein-Barbarossa bar-resistance curve for Rio Grande near Bernalillo, 1952 data. Curve from Einstein and Barbarossa, 1952.

velocities. Basic data for these calculations are given in table 5 .

From figures 6 and 7 , it is concluded that mean velocity may be predicted withm reasonable limits by the Einstein-Barbarossa method for the Rio Grande near Bernalillo and near Socorro.

\section{SUSPENDED-SEDIMENT DISTRIBUTION}

The vertical distribution of suspended-sediment concentration for several size ranges was determined from particle-size analysis of point-integrated samples. Data for the Bernalillo, Socorro, and Bernardo reaches are shown in table 2. The data show that suspended sediment less than $0.062 \mathrm{~mm}$ in diameter was almost uniformly distributed throughout the depth of flow. The vertical distribution of suspended sediment greater than $0.062 \mathrm{~mm}$ in diameter was defined for three size classes: $0.062-0.125 \mathrm{~mm}, 0.125-0.250 \mathrm{~mm}$, and 0.250 $0.50 \mathrm{~mm}$. Theoretical distributions for these size classes were computed using the fall velocities from figure 5 of "Inter-Agency Report No. 4," 1941, for the geometric mean of the size class.

Equation 4 plotted logarithmically is a straight line with a slope,

$Z_{1}=\frac{\log c_{y}}{\log \frac{D-y}{y}}=\begin{gathered}\text { measured exponent of suspended-sediment dis- } \\ \text { tribution. }\end{gathered}$

which may be read directly from the logarithmic plot of $c$ versus $(d-y) / y$. Figures 8 and 9 are typical plots using several sets of data from table 2. The plots show that $\log c$ varies directly with $\log (D-y) / y$, thus the distribution function is of the correct form. 


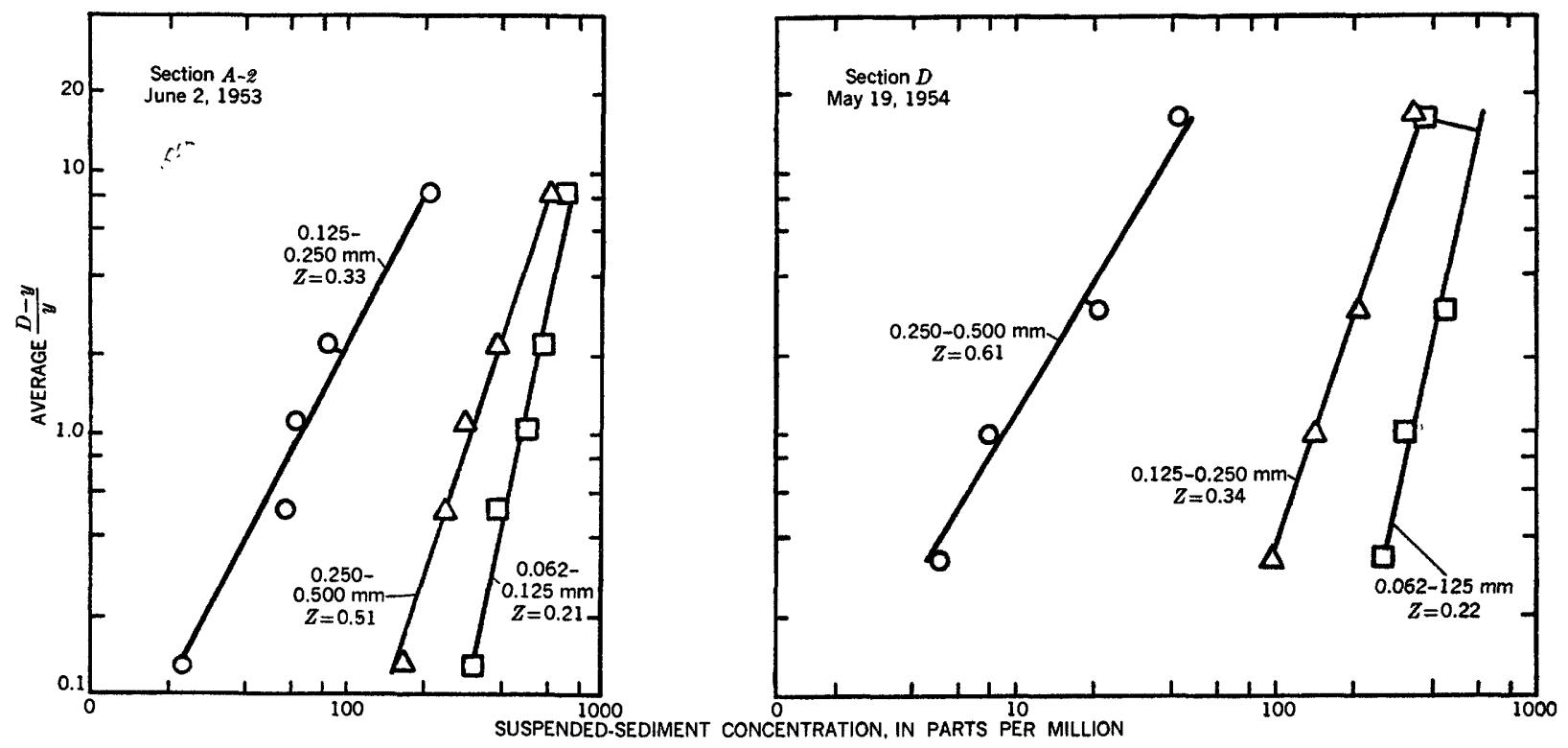

Figure 8.-Variation of concentration with $(D-y) / y$, Rio Grande near Bernalillo.
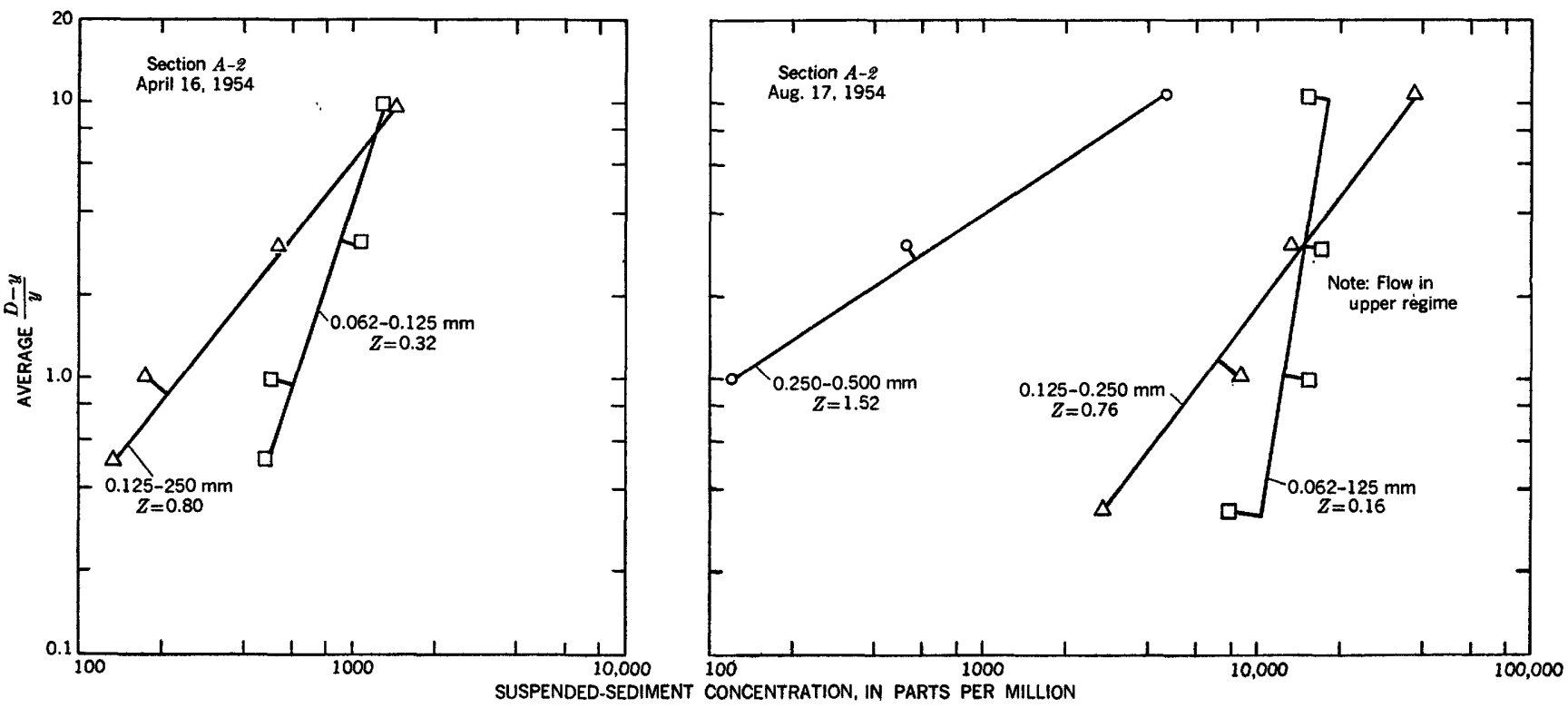

FigURE 9.--Variation of concentration with $(D-y) / y$, Rlo Grande near Socorro.

Values of $Z$ may be calculated from equation 5 , using the original assumptions as previously mentioned $(\beta=1, k=0.4)$. An alternate $Z$, designated $Z_{k}$, can be calculated assuming $\beta=1$ and using the computed $k$ from equation 8 . Values of $Z_{1}$, and $\beta=Z_{k} / Z$, are shown in table 4.

Figure 10 shows the plots of $Z_{1}$ versus $Z$ and $Z_{k}$ for the three size classes used herein. For small $Z$ or $Z_{k}$ values, $Z_{1}$ is generally in close agreement with $Z$ or $Z_{k}$. For large $Z$ or $Z_{k}$ values, $Z_{1}$ is smaller than $Z$ or $Z_{k}$, indicating the suspended sediment is distributed more uniformly than the theory would predict. The devia- tion of the computed exponent from the measured exponent becomes greater with increasing particle size. This is typical of the results found by Anderson (1942), Colby (1955), and others.

Points on the $Z_{1}$ versus $Z$ plot in figure 10 tend to group by reach along the ordinate $\left(Z_{1}\right)$ and by particle size along the abscissa $(Z)$. Grouping by particle size in $Z$ values is indicative of the limited range in shear velocity, $V_{*}$. On the $Z_{1}$ versus $Z_{k}$ plot, the points scatter and are more random, but the trend by reach is still evident. This apparent difference between $Z_{1}$ 's for the Bernalillo, Socorro, and Bernardo data may be 





attributed to the marked difference in average size of bed material (fig. 11) and to individual characteristics peculiar to each reach.

The curves in figure 11 are the average of the size distributions of bed material shown in table 3 . The median diameter of bed material in the Socorro reach was about $0.19 \mathrm{~mm}$ compared to $0.30 \mathrm{~mm}$ in the Bernalillo reach. The median diameter of bed material for the Bernardo data was in the clay-size range.

Some of the characteristics that may influence $Z_{1}$ values for the different reaches are flow regime and bed conditions. The Bernalillo data have low $\bar{V} / V_{*}{ }^{\prime \prime}$ values for a given $\psi^{\prime}$ (fig. 6) and high $k$ 's for low $C / \sqrt{g}$ values (fig. 5), thus indicating the persistence of dunes

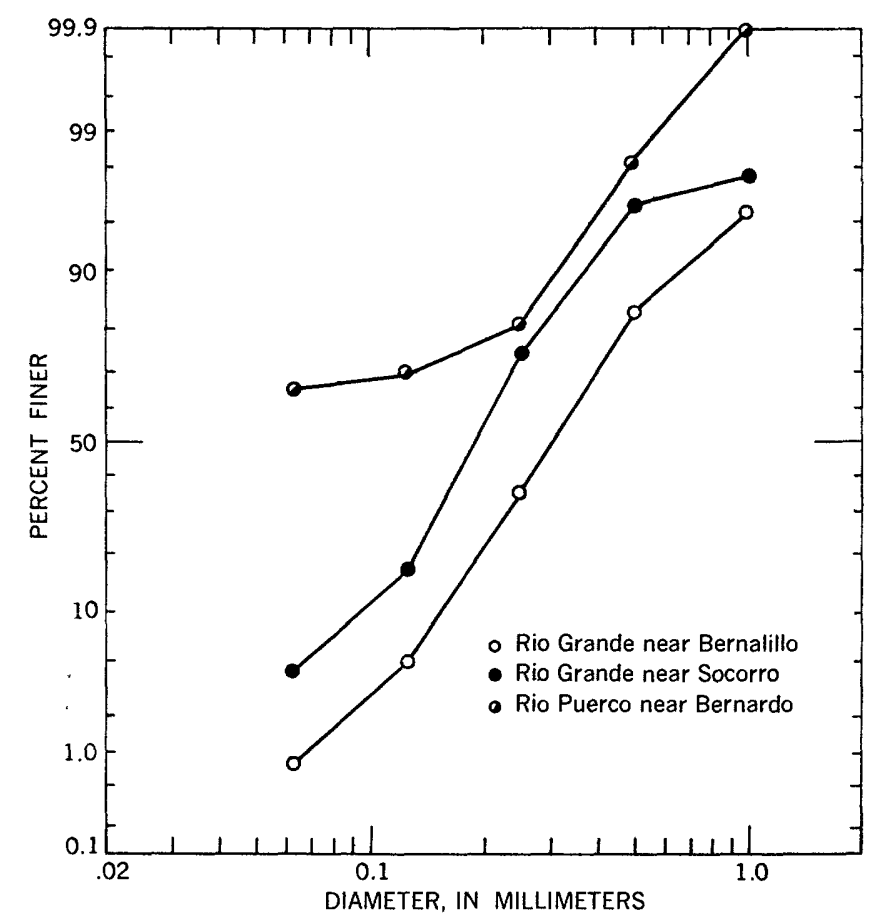

FiguRe 11.-Average particle-size distribution of bed material.

in this reach. The flow in the Socorro reach is mostly in transition and upper regime, while at Bernardo the bed was armored with clay. The launching of the particles into suspension may be different from a dune bed than from a plane bed. The suspended sand in the Bernardo reach is probably not from the bed, but is supplied from an upstream source. All these factors contribute to the apparent difference of the measured suspended-sediment distributions for Bernalillo, Socorro, and Bernardo.

Figure 12 shows $Z_{1}$ to vary curvilinearly with the fall velocity. For comparison, curves showing the variation of $Z_{1}$ with the 0.55 power of the fall velocity are plotted on the figure for the Bernalillo and Socorro reaches. When one point is high, the corresponding points for adjacent size classes are also high. Colby and Hembree (1955) found $Z_{1}$ to vary with the 0.7 power of the fall velocity in the Niobrara River. The suspended-sediment distribution is relatively more uniform for the Rio Grande than for the Niobrara River.

Vanoni (1946) and Ismail (1952) proposed that $\epsilon_{s}$ is not the same as $\epsilon_{m}$ but is related by the factor of proportionality $\beta=\epsilon_{s} / \epsilon_{m}$ where $\beta$ seems to be a function of particle size. Also

$$
Z_{1}=\frac{\omega}{\beta k V_{*}}=\frac{Z_{k}}{\beta} ; \beta=\frac{Z_{k}}{Z_{1}}
$$

thus $\beta$ indicates the deviation of $Z_{1}$ from $Z_{k}$.

Ismail (1952) found $\epsilon m$ affected only through changes in $k$ when sand was present. Values of $\epsilon_{m}$ could not be measured directly but could be evaluated by studying $\epsilon_{s}$ and the relations between $\epsilon_{m}$ and $\epsilon_{s}$. He found that $\beta=1.5$ for a $0.10 \mathrm{~mm}$ sand and 1.3 for a $0.16 \mathrm{~mm}$ sand.

Figure 13 shows the comparison of $k$ and $\beta$ for the three size classes used herein. Trend by size class is evident. When the value of $\beta$ for one size class is large, the corresponding $\beta$ 's for the other size classes are also high. Thus the trend is consistent within itself. $\beta$ and $k$ are intimately related. It is noted that at $k=0.4$, average values of $\beta$ are approximately $0.85,1.4$, and 2.2 or greater for the $0.062-0.125 \mathrm{~mm}, 0.125-0.250$ $\mathrm{mm}, 0.250-0.500 \mathrm{~mm}$ size classes, respectively. The value 1.4 compares favorably with Ismail's value of 1.3 for $0.16 \mathrm{~mm}$ sand. Ismail's $k$ values were slightly less than 0.4. From Ismail's findings, $\beta$ decreased with increasing particle size. For the data herein, $\beta$ increases with increasing particle size and with decreasing roughness. It is of special interest that $\beta$ values are closest to 1.0 for lower regime flow, where $k$ values vary upward to about 1.2 ; while for upper regime flow, where $k$ ranges from about 0.2 to $0.4, \beta$ varies upward to about 9 . This indicates that for flow over a dune bed the predicted suspended-sediment distribution follows approximately the measured distribution; for flow over a plane bed, the predicted suspended-sediment distribution deviates considerably from the measured distribution. On the other hand, measured velocity distribution for upper regime flow follows a predicted distribution $(k \approx 0.4)$, while for lower regime flow the velocity distribution is more uniform than predicted $(k \gg 0.4)$. These relations are shown qualitatively in figure 14.

Einstein and Chien (1954) presented several approaches to the solution of the suspended load theory using various assumptions on the nature of the mixing length and turbulence characteristics. All of the approaches are cumbersome and require that experimentally determined constants be selected on the basis of measured data. The approach which most closely 


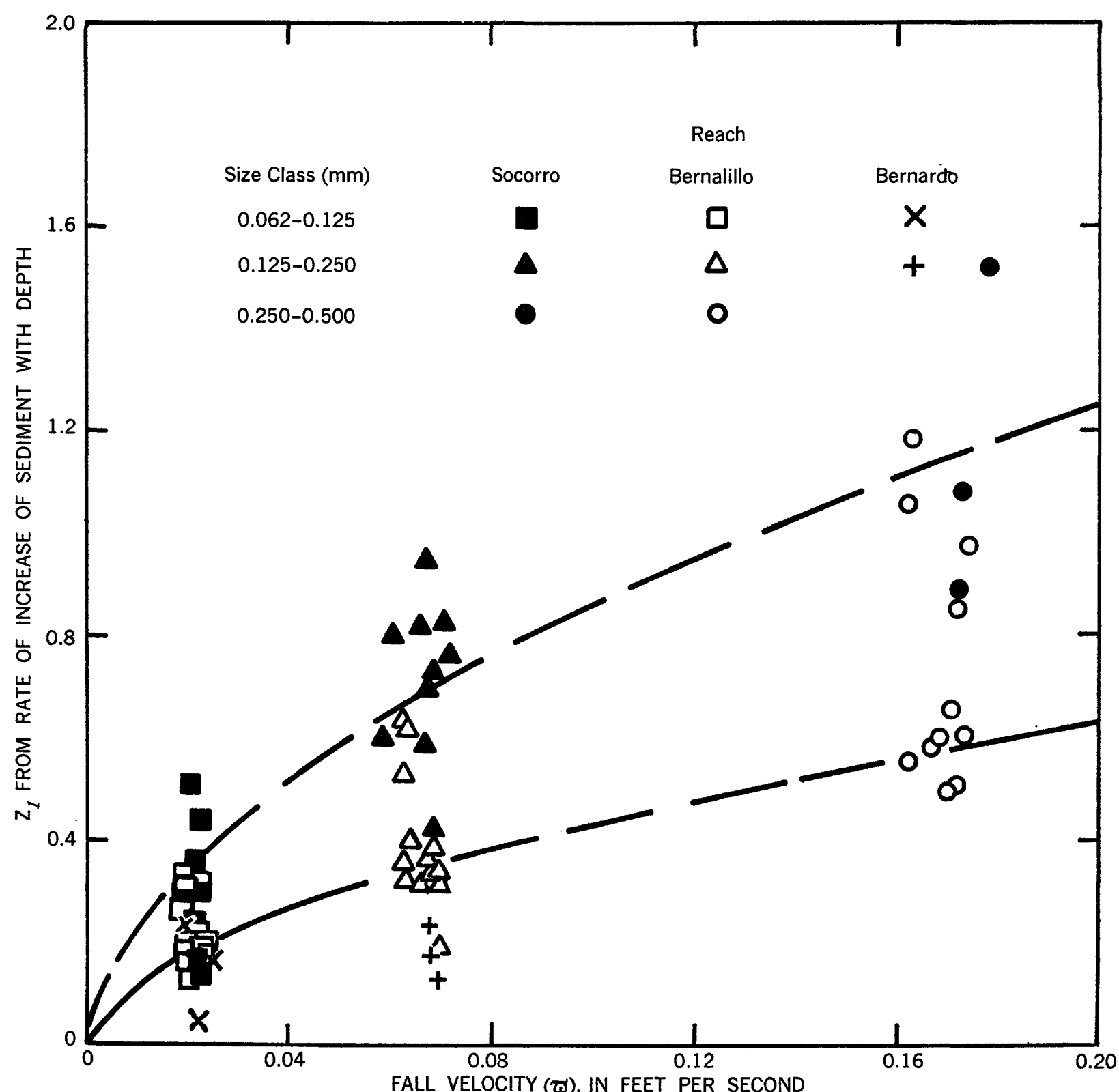

FIGURE 12.-Variation of $Z_{1}$ and fall velocity.

fits the measured suspended-sediment distribution herein is given by the following equation:

$\frac{c_{y}}{c_{a}}=\left[\frac{1-\sqrt{\frac{D-a}{D}}}{1-\sqrt{\frac{D-y}{D}}}\right]^{\frac{Z}{1+N k Z}}\left[\frac{1+\sqrt{\frac{D-a}{D}}}{1+\sqrt{\frac{D-y}{D}}}\right]^{\frac{Z}{1-N k Z}}$

$$
\left[\frac{\sqrt{\frac{D-a}{D}}+N k Z}{\sqrt{\frac{D-y}{D}}+N k Z}\right]^{\frac{2 Z}{N^{2 k^{2} Z^{2}-1}}}
$$

where

$N=$ an experimentally determined constant $Z=\omega / k V_{*}$
In deriving this equation, Einstein and Chien assumed that the turbulence was unsymmetric. Equation 13 using a value of $N k=0.4$ is shown on figure 10 . The equation generally fits the trend of the measured data throughout the range of values. It should be noted that the distribution function given by equation 13 is changed from the functional relation of equation 4, but the suspended-sediment distribution can still be approximated by a straight line for a plot of $c$ versus $(D-y) / y$ on a logarithmic plot. For small $Z$ values in equation 13 .

$$
\frac{c_{y}}{c_{a}} \rightarrow\left(\frac{D-y}{y} \cdot \frac{a}{d-a}\right)^{Z}
$$




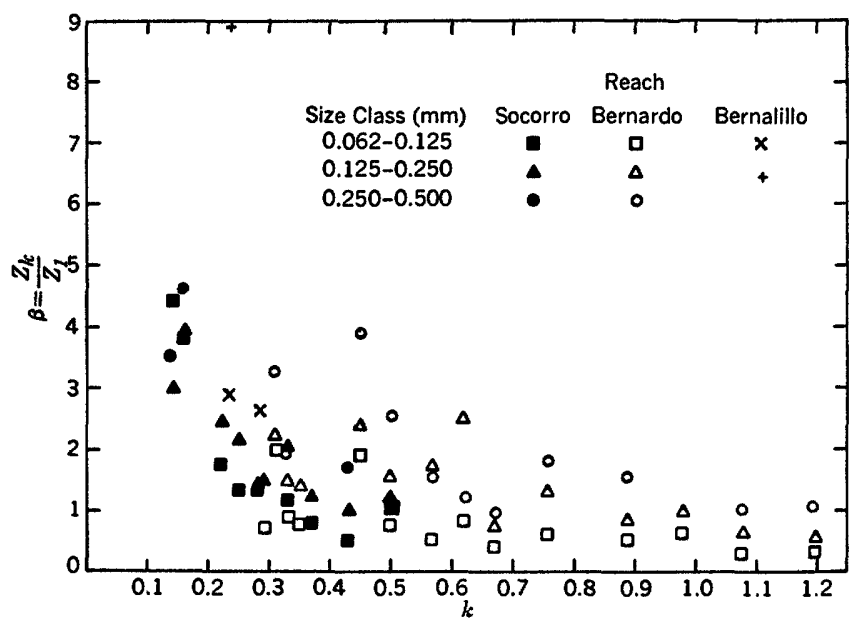

FiguRE 13.-Variation of $k$ and $\beta$.
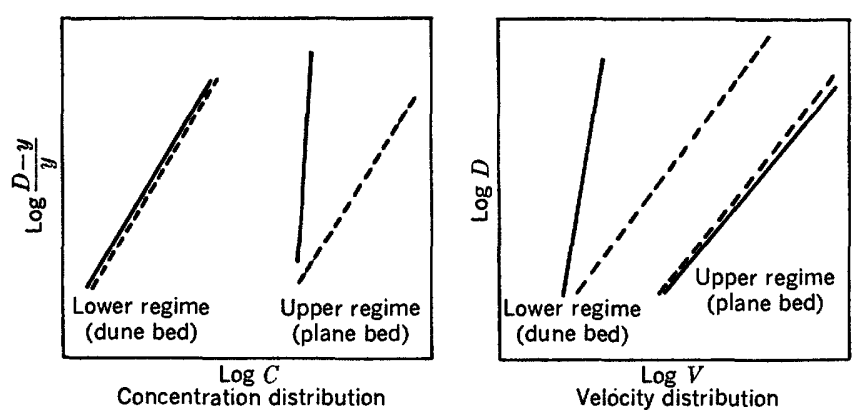

FiGURE 14,-Qualitative relation of predicted and measured velocity and suspendedsediment distribution for lower regime flow and upper regime flow. Predicted distribution, dashed line; measured distribution, solid line.

Einstein and Chien (1954) favored an approach where mixing length and velocity fluctuations of turbulent flow tollow certain probability distributions, and the higher derivative terms of the concentration gradient are included. For low $Z$ values, this approach does not fit the data herein as well as that given by equation 13.

Einstein (1950) used the shear velocity with respect to the sand grain, $V_{*}^{\prime}$, in equation 5 to compute the distribution exponent $Z$. Values of $Z$ computed in this manner show the same trend as indicated in figure 10 . Because $V_{*}^{\prime}<V_{*}$, the values of $Z$ deviate even further from the measured values than those computed using $V_{*}$. Vanoni and Brooks (1957) have questioned the use of $V_{*}^{\prime}$ in computing the distribution exponent $Z$.

In modifying the suspended-sediment distribution theory, Einstein and Chien (1954) used $V_{*}=\sqrt{g D S}$ to compute values of $Z$. Presumably, the flow was over a plane bed, and it was implied that for flow over a dune bed, $V_{*}{ }^{\prime}$ should be used. For most field data, $V_{*}{ }^{\prime}$ is less than $V_{*}$, even for upper regime flow; that is, there are always some additional trictional losses beyond those due to the grain roughness only. Thus, in using the approaches suggested by Einstein and Chien, and in defining the constants, for example $N$ in equation 13 , it is important that the shear velocity used in computing the values of $Z$ be consistent throughout.

Einstein and Chien (1955) also suggest that $k$ from the graphical relation of figure 4 be used in computing $Z$. For the data presented herein, the relation does not define the value of $k$ for lower regime flow.

\section{EFFECTS OF HIGH CONCENTRATIONS ON FALL VELOCITY}

The observations of velocity and concentration distributions for the Rio Puerco near Bernardo and for the Rio Grande near Socorro (August 17, 1954) were obtained in flows which carried high concentrations of fine material $(<0.062 \mathrm{~mm})$ in suspension. The Socorro flow was inflow from the Rio Puerco.

The Rio Puerco flows intermittently. Concentrations of fine material of $100,000 \mathrm{ppm}$ (parts per million) are common, and concentrations up to $400,000 \mathrm{ppm}$ are not unusual. Core samples of the bed of the Rio Puerco show the bed material to be a fine sand with a size distribution similar to that of the Socorro reach $\left(d_{50} \approx 0.20 \mathrm{~mm}\right)$. As flow recedes, clay impregnates the bed to a depth of about 0.6 foot. When the bed dries, this clay-impregnated layer hardens into an armor coating.

When the bed of the Rio Puerco is armored with clay, the concentrations of suspended sand are low, probably because the material is not readily available for transport. When the clay layer is broken up, and flow is over the sand bed, the capacity of the Rio Puerco to transport sand is several times greater than the capacity of a stream with comparable flow of clear water or flow carrying negligible concentrations of fine material. The major factors which contribute to this increased capacity for transport are the increase in viscosity and mass density of the fluid and the concurrent decrease in the fall velocity of the sediment (Simons and others, 1961).

The general effects of concentration on fall velocity in sedimentation chambers have been investigated ("Inter-Agency Report No. 12, 1957"), but the overall effects of high concentrations under natural stream conditions are not known. Figure 15 shows the apparent reduction in fall velocity at $24^{\circ} \mathrm{C}$ for various concentrations of fine material for the geometric mean diameters of the three size classes used in this report. This figure was developed from visual accumulation tube analyses of bed material in clear water and in native water of the Rio Puerco with varying concentrations of suspended fine material. The reduction in fall velocity thus includes the effects of the dissolved solids as well as the effects of the fine material. 


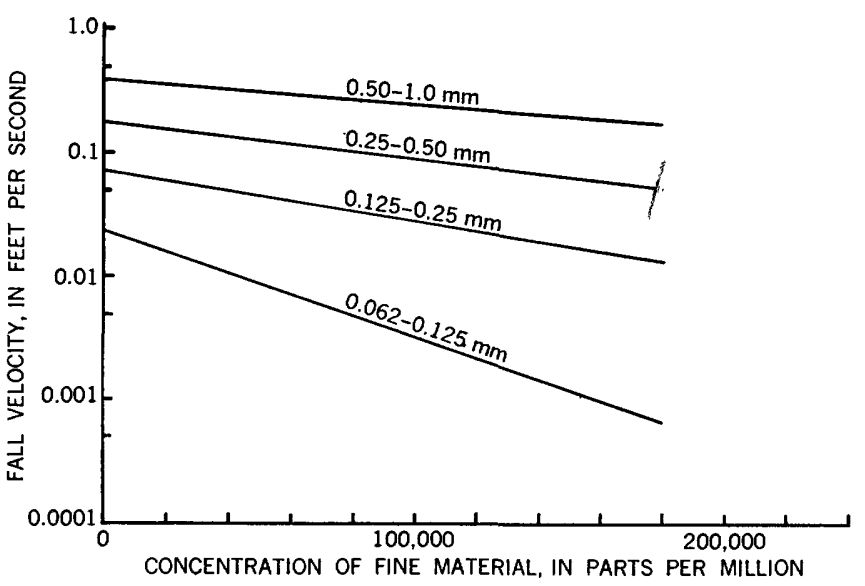

Figure 15.--Variation of fall velocity with concentration of fine material.

Figure 15 was developed from limited data and should be considered tentative. The reduction of fall velocity with increased concentration in the visual accumulation tube is probably not quantitatively comparable to the reduction in fall velocity which actually occurs in the stream, but figure 15 shows clearly that the effect of concentration on fall velocity is appreciable for the range of conditions encountered in the Rio Puerco flow. If the fall velocities from figure 15 are assumed applicable in computing $Z$, values of the computed sediment distribution exponent show much closer agreement with the measured exponent $Z_{1}$ for the high concentration flows at Bernardo and Socorro (fig. 16). The effect of concentration on fall velocity for concentra-

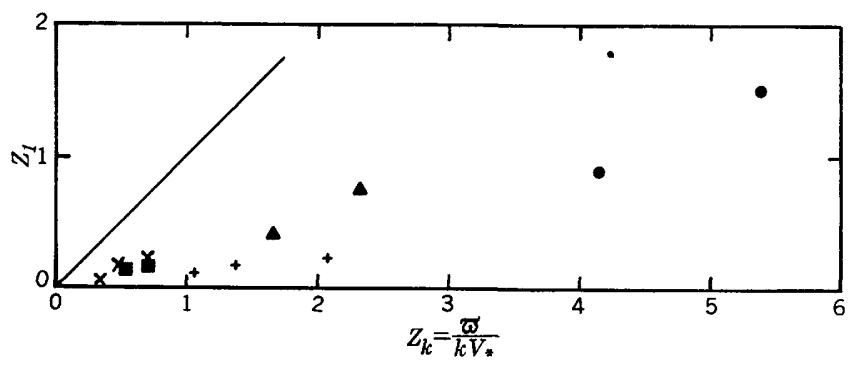

$A$

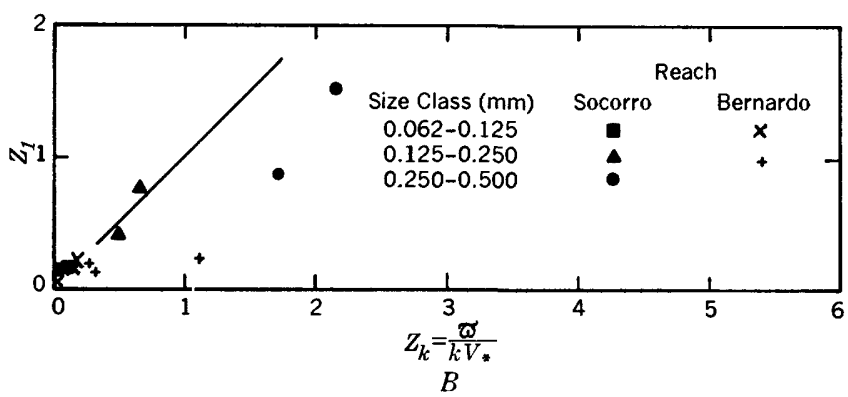

Figure 16.-Comparison of measured sediment distribution exponent, $Z_{1}$, with the exponent, $\boldsymbol{Z}_{k}$, computed (a) using fall velocities in distilled water, and (b) using fall velocities from figure 15 . tions less than about $10,000 \mathrm{ppm}$ in the Rio Puerco and middle Rio Grande is negligible for practical purposes.

\section{CONCLUSIONS}

For the data presented, measured values of vertical velocity and suspended-sediment concentration distributions were compared with values predicted from theoretical considerations. The data included observations of flow in lower regime, transition zone, several in upper regime, and several with high suspendedsediment concentrations. Results and conclusions, some of which may be applicable only for this study, are summarized as follows:

1. For flow over a dune bed, the predicted suspendedsediment distribution follows approximately the measured distribution, and the velocity distribution is more uniform than predicted; while for flow over a plane bed, the predicted suspended-sediment distribution deviates considerably from the measured distribution, and the velocity distribution follows approximately the predicted distribution.

2. Mean velocity for the Rio Grande near Bernalillo and near Socorro is adequately described by the Einstein-Barbarossa bar-resistance relation.

3. For a given reach the range of values for $K_{s}$ depends on bed configuration. However, the average value of $K_{s}$ for a reach does not appear to be related to bed configuration, but depends upon size of bed material. For the three reaches, the average value of $K_{s}$ is approximately 400 times as large as $d_{65}$.

4. The value of the coefficient of turbulent exchange, $k$, decreases with high concentration for upper regime flow; and varies widely for lower regime flow, probably due to a three-dimensional flow effect. There is not apparent effect of concentration on $k$ for flow over a dune bed. The coefficient $k$ appears to decrease with decreasing bed roughness as measured indirectly by $C / \sqrt{g}$ for transition and upper regime flow.

5. The suspended sediment is distributed more uniformly than conventional theory predicts. The deviation of the measured exponent, $Z_{1}$, from the computed exponent, $Z$, becomes greater with increasing particle size. Differences between measured and computed values of $Z$ are due to flow regime, to size of bed material, and to the effects of the concentrations of suspended fine material.

6. The measured exponent, $Z_{1}$, varies with about the 0.55 power of the fall velocity.

7. The factor of proportionality $\beta$ increases with increasing particle size and with decreasing roughness. Values of $\beta$ are closest to 1.0 for flow over a dune bed.

8. Fall velocity is effectively decreased in flows with concentrations greater than about $10,000 \mathrm{ppm}$. 
BASIC DATA AND COMPUTED PARAMETERS

TABLE 1.-Velocity distribution

\begin{tabular}{|c|c|c|c|c|c|c|c|c|c|c|c|c|c|c|c|}
\hline \multirow{3}{*}{ Date } & \multirow{3}{*}{ Reach } & \multirow{3}{*}{ Section } & \multirow{3}{*}{$\begin{array}{c}\text { No. of } \\
\text { vertical }\end{array}$} & \multirow{3}{*}{ Temp } & \multirow{3}{*}{ D } & \multicolumn{10}{|c|}{ Horizon } \\
\hline & & & & & & \multicolumn{2}{|c|}{$\mathbf{A}$} & \multicolumn{2}{|c|}{ B } & \multicolumn{2}{|c|}{$\mathrm{o}$} & \multicolumn{2}{|c|}{ D } & \multicolumn{2}{|c|}{$\mathbf{E}$} \\
\hline & & & & & & $y$ & v & $y$ & $v$ & $y$ & 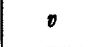 & $y$ & v & $y$ & v \\
\hline \multirow[t]{3}{*}{$6-2-53$} & Bernalillo_..... & A-2 & $\begin{array}{l}1 \\
2 \\
3 \\
4 \\
5\end{array}$ & $\begin{array}{c}{ }^{\circ} \mathrm{F} \\
71 \\
70 \\
70\end{array}$ & $\begin{array}{l}f t \\
\text { 3. } 0 \\
\text { 3. } 0 \\
\text { 2. } 6 \\
\text { 3. } 0 \\
\text { 2. } 6\end{array}$ & $\begin{array}{c}f t \\
0.30 \\
.30 \\
.30 \\
.30 \\
.30\end{array}$ & \begin{tabular}{|c|} 
ft per sec \\
2.68 \\
2.75 \\
3.74 \\
1.84 \\
3.26
\end{tabular} & $\begin{array}{r}\text { ft } \\
\text { 1. } 00 \\
\text { 1. } 00 \\
.80 \\
\text { 1. } 00 \\
.80\end{array}$ & \begin{tabular}{|c} 
ft per sec \\
3.26 \\
3.10 \\
3.94 \\
3.30 \\
3.90
\end{tabular} & $\begin{array}{c}\text { ft } \\
1.50 \\
1.50 \\
1.20 \\
1.50 \\
1.20\end{array}$ & \begin{tabular}{|c} 
ft per sec \\
3.58 \\
3.38 \\
4.08 \\
4.28 \\
4.04
\end{tabular} & $\begin{array}{c}f t \\
2.00 \\
2.00 \\
\text { 1. } 70 \\
\text { 2. } 00 \\
1.70\end{array}$ & \begin{tabular}{|c} 
ft per sec \\
3.58 \\
3.51 \\
4.04 \\
4.66 \\
4.28
\end{tabular} & $\begin{array}{l}\stackrel{f t}{f t} \\
2.70 \\
2.70 \\
2.20 \\
2.70 \\
2.20\end{array}$ & $\begin{array}{r}f t \text { per sec } \\
3.38 \\
3.54 \\
3.99 \\
4.38 \\
4.54\end{array}$ \\
\hline & & & $\begin{array}{r}6 \\
7 \\
8 \\
9 \\
10\end{array}$ & $\begin{array}{l}70 \\
70 \\
71 \\
71 \\
71\end{array}$ & $\begin{array}{l}2.7 \\
2.5 \\
2.5 \\
2.5 \\
2.4\end{array}$ & $\begin{array}{l}.30 \\
.30 \\
.30 \\
.30 \\
.30\end{array}$ & $\begin{array}{l}3.51 \\
2.45 \\
2.87 \\
1.88 \\
2.08\end{array}$ & $\begin{array}{l}.80 \\
.80 \\
.80 \\
.80 \\
.80\end{array}$ & $\begin{array}{l}\text { 3. } 82 \\
\text { 3. } 70 \\
\text { 3. } 00 \\
\text { 2. } 36 \\
\text { 2. } 18\end{array}$ & $\begin{array}{l}\text { 1. } 20 \\
\text { 1. } 20 \\
\text { 1. } 20 \\
\text { 1. } 20 \\
\text { 1. } 20\end{array}$ & $\begin{array}{l}3.74 \\
3.74 \\
3.00 \\
2.75 \\
2.30\end{array}$ & $\begin{array}{l}\text { 1. } 70 \\
\text { 1. } 70 \\
\text { 1. } 70 \\
\text { 1. } 70 \\
\text { 1. } 60\end{array}$ & $\begin{array}{l}3.74 \\
3.90 \\
2.81 \\
2.81 \\
2.25\end{array}$ & $\begin{array}{l}\text { 2. } 20 \\
2.20 \\
2.20 \\
2.20 \\
2.10\end{array}$ & $\begin{array}{l}3.74 \\
\text { 3. } 94 \\
2.75 \\
2.72 \\
\text { 2. } 28\end{array}$ \\
\hline & & & $\begin{array}{l}11 \\
12 \\
13 \\
14 \\
15\end{array}$ & $\begin{array}{l}71 \\
71 \\
71 \\
72 \\
71\end{array}$ & $\begin{array}{l}\text { 2. } 5 \\
\text { 4. } 0 \\
\text { 5. } 0 \\
\text { 5. } 0 \\
\text { 5. } 4\end{array}$ & $\begin{array}{l}.30 \\
.40 \\
.50 \\
.50 \\
.50\end{array}$ & $\begin{array}{l}1.84 \\
2.08 \\
1.48 \\
2.87 \\
1.01\end{array}$ & $\begin{array}{r}.80 \\
1.20 \\
1.40 \\
1.50 \\
1.70\end{array}$ & $\begin{array}{l}1.88 \\
2.20 \\
2.01 \\
\text { 3. } 00 \\
2.10\end{array}$ & $\begin{array}{l}\text { 1. } 20 \\
2.00 \\
2.30 \\
2.50 \\
2.70\end{array}$ & $\begin{array}{l}2.36 \\
2.50 \\
2.53 \\
3.00 \\
2.53\end{array}$ & $\begin{array}{l}\text { 1. } 70 \\
\text { 2. } 80 \\
\text { 3. } 10 \\
\text { 3. } 50 \\
\text { 3. } 80\end{array}$ & $\begin{array}{l}2.62 \\
2.75 \\
2.75 \\
2.81 \\
2.72\end{array}$ & $\begin{array}{l}2.20 \\
3.60 \\
\text { 4. } 50 \\
\text { 4. } 50 \\
\text { 4. } 90\end{array}$ & $\begin{array}{l}2.65 \\
2.81 \\
2.90 \\
2.75 \\
2.65\end{array}$ \\
\hline \multirow[t]{4}{*}{$4-53$} & ..... do & $A-2$ & $\begin{array}{l}1 \\
2 \\
3\end{array}$ & $\begin{array}{l}62 \\
62 \\
63\end{array}$ & $\begin{array}{l}2.5 \\
2.0 \\
2.5\end{array}$ & $\begin{array}{l}.30 \\
.30 \\
.30\end{array}$ & $\begin{array}{l}\text { 3. } 35 \\
\text { 2. } 87 \\
\text { 3. } 26\end{array}$ & $\begin{array}{l}.80 \\
.60 \\
.80\end{array}$ & $\begin{array}{l}\text { 4. } 18 \\
\text { 3. } 21 \\
\text { 3. } 38\end{array}$ & $\begin{array}{l}\text { 1. } 30 \\
\text { 1. } 00 \\
\text { 1. } 30\end{array}$ & $\begin{array}{l}\text { 4. } 38 \\
2.93 \\
\text { 3. } 70\end{array}$ & $\begin{array}{l}\text { 1. } 70 \\
\text { 1. } 40 \\
\text { 1. } 70\end{array}$ & $\begin{array}{l}\text { 4. } 38 \\
\text { 2. } 90 \\
\text { 3. } 74\end{array}$ & $\begin{array}{l}2.20 \\
1.70 \\
2.20\end{array}$ & $\begin{array}{l}\text { 4. } 18 \\
\text { 2. } 62 \\
\text { 3. } 74\end{array}$ \\
\hline & & $\mathbf{A}$ & $\begin{array}{l}1 \\
2 \\
3\end{array}$ & & $\begin{array}{l}\text { 3. } 5 \\
\text { 4. } 6 \\
\text { 4. } 6\end{array}$ & $\begin{array}{l}.30 \\
.40 \\
.40\end{array}$ & $\begin{array}{l}\text { 3. } 72 \\
\text { 4. } 36 \\
\text { 4. } 74\end{array}$ & $\begin{array}{l}1.00 \\
1.20 \\
1.20\end{array}$ & $\begin{array}{l}4.09 \\
4.59 \\
5.00\end{array}$ & $\begin{array}{l}\text { 1. } 75 \\
\text { 2. } 30 \\
\text { 2. } 30\end{array}$ & $\begin{array}{l}\text { 4. } 36 \\
\text { 5. } 06 \\
\text { 5. } 44\end{array}$ & $\begin{array}{l}\text { 2. } 50 \\
\text { 3. } 20 \\
\text { 3. } 20\end{array}$ & $\begin{array}{l}\text { 4. } 36 \\
\text { 5. } 18 \\
\text { 5. } 06\end{array}$ & $\begin{array}{l}\text { 3. } 20 \\
4.20 \\
4.20\end{array}$ & $\begin{array}{l}\text { 4. } 25 \\
\text { 4. } 84 \\
\text { 4. } 50\end{array}$ \\
\hline & & $\mathrm{C}$ & $\begin{array}{l}1 \\
2 \\
3\end{array}$ & $\begin{array}{l}70 \\
71 \\
71\end{array}$ & $\begin{array}{l}\text { 1. } 6 \\
\text { 2. } 7 \\
\text { 3. } 2\end{array}$ & $\begin{array}{l}.30 \\
.30 \\
.40\end{array}$ & $\begin{array}{r}.75 \\
2.56 \\
1.21\end{array}$ & $\begin{array}{r}.60 \\
.80 \\
1.00\end{array}$ & $\begin{array}{l}\text { 1. } 06 \\
\text { 3. } 07 \\
\text { 3. } 10\end{array}$ & $\begin{array}{r}.80 \\
\text { 1. } 40 \\
\text { 1. } 60\end{array}$ & $\begin{array}{l}\text { 1. } 21 \\
\text { 3. } 14 \\
\text { 3. } 51\end{array}$ & $\begin{array}{l}\text { 1. } 00 \\
\text { 1. } 90 \\
\text { 2. } 20\end{array}$ & $\begin{array}{l}\text { 1. } 50 \\
\text { 3. } 32 \\
\text { 3. } 90\end{array}$ & $\begin{array}{l}\text { 1. } 30 \\
\text { 2. } 40 \\
\text { 2. } 80\end{array}$ & $\begin{array}{l}\text { 1. } 61 \\
\text { 3. } 08 \\
\text { 3. } 94\end{array}$ \\
\hline & & $\mathrm{E}$ & $\begin{array}{l}1 \\
2 \\
3\end{array}$ & $-\overline{70}$ & $\begin{array}{l}\text { 3. } 8 \\
\text { 1. } 6 \\
\text { 2. } 1\end{array}$ & $\begin{array}{l}.50 \\
.30 \\
.30\end{array}$ & $\begin{array}{l}\text { 3. } 43 \\
\text { 2. } 61 \\
\text { 3. } 25\end{array}$ & $\begin{array}{r}1.20 \\
.55 \\
.70\end{array}$ & $\begin{array}{l}\text { 3. } 76 \\
\text { 2. } 67 \\
\text { 3. 51 }\end{array}$ & $\begin{array}{r}1.90 \\
.80 \\
1.10\end{array}$ & $\begin{array}{l}4.02 \\
2.86 \\
3.38\end{array}$ & $\begin{array}{l}2.60 \\
1.05 \\
1.50\end{array}$ & $\begin{array}{l}\text { 4. } 06 \\
2.77 \\
\text { 3. } 30\end{array}$ & $\begin{array}{l}3.30 \\
1.30 \\
1.80\end{array}$ & $\begin{array}{l}\text { 4. } 15 \\
\text { 2. } 74 \\
\text { 3. } 07\end{array}$ \\
\hline \multirow[t]{4}{*}{$4-13-54$} & .....do do & B & $\begin{array}{l}1 \\
2 \\
3 \\
4 \\
5\end{array}$ & $\begin{array}{l}61 \\
61 \\
61 \\
62 \\
63\end{array}$ & $\begin{array}{l}1.5 \\
1.1 \\
1.7 \\
1.5 \\
2.5\end{array}$ & $\begin{array}{l}.20 \\
.20 \\
.20 \\
.20 \\
.20\end{array}$ & $\begin{array}{l}1.38 \\
1.88 \\
1.23 \\
1.08 \\
1.84\end{array}$ & $\begin{array}{l}.38 \\
.28 \\
.42 \\
.38 \\
.62\end{array}$ & $\begin{array}{l}\text { 1. } 88 \\
2.15 \\
2.10 \\
1.47 \\
2.80\end{array}$ & $\begin{array}{r}.75 \\
.55 \\
.85 \\
.75 \\
1.25\end{array}$ & $\begin{array}{l}2.24 \\
2.20 \\
2.15 \\
1.92 \\
3.43\end{array}$ & $\begin{array}{r}1.20 \\
.88 \\
1.36 \\
1.20 \\
2.00\end{array}$ & $\begin{array}{l}2.34 \\
\text { 1. } 96 \\
\text { 2. } 29 \\
\text { 2. } 00 \\
\text { 3. } 64\end{array}$ & & \\
\hline & & C & $\begin{array}{l}1 \\
2 \\
3 \\
4 \\
5\end{array}$ & $\begin{array}{l}63 \\
64 \\
64 \\
64 \\
63\end{array}$ & $\begin{array}{r}1.5 \\
.8 \\
1.1 \\
2.5 \\
4.4\end{array}$ & $\begin{array}{l}.20 \\
.20 \\
.20 \\
.20 \\
.20\end{array}$ & $\begin{array}{l}1.58 \\
1.88 \\
2.49 \\
1.23 \\
1.50\end{array}$ & $\begin{array}{r}.38 \\
.20 \\
.28 \\
.62 \\
1.10\end{array}$ & $\begin{array}{l}1.80 \\
1.96 \\
2.49 \\
1.92 \\
3.02\end{array}$ & $\begin{array}{r}.75 \\
.40 \\
.55 \\
1.20 \\
2.20\end{array}$ & $\begin{array}{l}1.96 \\
2.22 \\
2.61 \\
2.05 \\
\text { 3. } 33\end{array}$ & $\begin{array}{r}1.20 \\
.64 \\
.88 \\
2.00 \\
3.52\end{array}$ & $\begin{array}{l}1.94 \\
1.73 \\
2.42 \\
\text { 2. } 00 \\
\text { 3. } 50\end{array}$ & & \\
\hline & & $\mathrm{D}$ & $\begin{array}{l}1 \\
2 \\
3 \\
4 \\
5\end{array}$ & $\begin{array}{l}63 \\
63 \\
63 \\
63 \\
63\end{array}$ & $\begin{array}{l}2.0 \\
1.9 \\
1.6 \\
1.8 \\
2.2\end{array}$ & $\begin{array}{l}.30 \\
.30 \\
.30 \\
.30 \\
.30\end{array}$ & $\begin{array}{l}.43 \\
1.16 \\
2.47 \\
1.72 \\
2.65\end{array}$ & $\begin{array}{l}.50 \\
.50 \\
.40 \\
.50 \\
.60\end{array}$ & $\begin{array}{l}.78 \\
1.12 \\
2.42 \\
1.90 \\
2.77\end{array}$ & $\begin{array}{r}1.00 \\
1.00 \\
.80 \\
.90 \\
1.10\end{array}$ & $\begin{array}{l}2.33 \\
2.33 \\
2.80 \\
2.15 \\
2.89\end{array}$ & $\begin{array}{l}1.50 \\
1.40 \\
1.10 \\
1.30 \\
1.70\end{array}$ & $\begin{array}{l}\text { 2. } 28 \\
\text { 2. 50 } \\
\text { 2. } 80 \\
\text { 2. } 33 \\
\text { 2. } 89\end{array}$ & & \\
\hline & & $\mathrm{E}$ & $\begin{array}{l}1 \\
2 \\
3 \\
4 \\
5\end{array}$ & $\begin{array}{l}62 \\
62 \\
62 \\
62 \\
61\end{array}$ & $\begin{array}{l}1.7 \\
2.7 \\
2.0 \\
2.5 \\
2.1\end{array}$ & $\begin{array}{l}.30 \\
.30 \\
.30 \\
.30 \\
.30\end{array}$ & $\begin{array}{l}2.13 \\
1.14 \\
2.23 \\
1.10 \\
1.50\end{array}$ & $\begin{array}{l}.50 \\
.60 \\
.40 \\
.60 \\
.60\end{array}$ & $\begin{array}{l}2.13 \\
1.40 \\
2.20 \\
1.28 \\
1.86\end{array}$ & $\begin{array}{r}.80 \\
1.20 \\
.80 \\
1.20 \\
1.10\end{array}$ & $\begin{array}{l}2.30 \\
1.66 \\
2.40 \\
1.82 \\
1.92\end{array}$ & $\begin{array}{l}1.20 \\
2.20 \\
1.50 \\
\text { 2. } 00 \\
1.60\end{array}$ & $\begin{array}{l}\text { 2. } 50 \\
\text { 1. } 90 \\
\text { 2. } 47 \\
\text { 2. } 42 \\
\text { 1. } 90\end{array}$ & & \\
\hline \multirow[t]{2}{*}{$5-19-54$} & _._. do & B & $\begin{array}{l}1 \\
2 \\
3 \\
4 \\
5\end{array}$ & $\begin{array}{l}70 \\
69 \\
68 \\
67 \\
65\end{array}$ & $\begin{array}{l}4.7 \\
4.6 \\
2.6 \\
1.8 \\
1.9\end{array}$ & $\begin{array}{l}.20 \\
.20 \\
.20 \\
.20 \\
.20\end{array}$ & $\begin{array}{l}\text { 3. } 05 \\
2.80 \\
3.32 \\
1.51 \\
1.84\end{array}$ & $\begin{array}{r}1.18 \\
1.15 \\
.65 \\
.45 \\
.48\end{array}$ & $\begin{array}{l}3.57 \\
3.50 \\
4.06 \\
2.00 \\
2.20\end{array}$ & $\begin{array}{r}2.35 \\
2.30 \\
1.30 \\
.90 \\
.95\end{array}$ & $\begin{array}{l}\text { 3. } 97 \\
\text { 3. } 97 \\
4.25 \\
2.49 \\
2.05\end{array}$ & $\begin{array}{l}\text { 3. } 52 \\
\text { 3. } 45 \\
\text { 1. } 95 \\
\text { 1. } 35 \\
\text { 1. } 42\end{array}$ & $\begin{array}{l}\text { 4. } 02 \\
\text { 4. } 36 \\
\text { 4. } 36 \\
\text { 2. } 86 \\
\text { 2. } 05\end{array}$ & 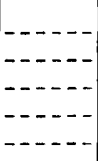 & \\
\hline & & $\mathrm{C}$ & $\begin{array}{l}1 \\
2 \\
3 \\
4 \\
5\end{array}$ & $\begin{array}{l}72 \\
74 \\
74 \\
73 \\
73\end{array}$ & $\begin{array}{l}5.0 \\
1.6 \\
2.0 \\
2.1 \\
2.1\end{array}$ & $\begin{array}{l}.15 \\
.15 \\
.15 \\
.15 \\
.15\end{array}$ & $\begin{array}{r}1.32 \\
.84 \\
1.76 \\
1.58 \\
1.84\end{array}$ & $\begin{array}{r}1.25 \\
.40 \\
.50 \\
.52 \\
.52\end{array}$ & $\begin{array}{l}2.67 \\
1.62 \\
2.05 \\
2.25 \\
2.25\end{array}$ & $\begin{array}{r}2.50 \\
\text { 1. } 80 \\
\text { 1. } 05 \\
\text { 1. } 05\end{array}$ & $\begin{array}{l}3.13 \\
1.54 \\
1.70 \\
2.49 \\
2.49\end{array}$ & $\begin{array}{l}\text { 3. } 75 \\
1.20 \\
1.50 \\
1.58 \\
1.58\end{array}$ & $\begin{array}{l}\text { 3. } 20 \\
1.08 \\
2.15 \\
2.55 \\
2.44\end{array}$ & & \\
\hline
\end{tabular}


DISTRIBUTION OF VELOCITY AND SUSPENDED SEDIMENT, MIDDLE RIO GRANDE

TABLE 1.-Velocity distribution-Continued

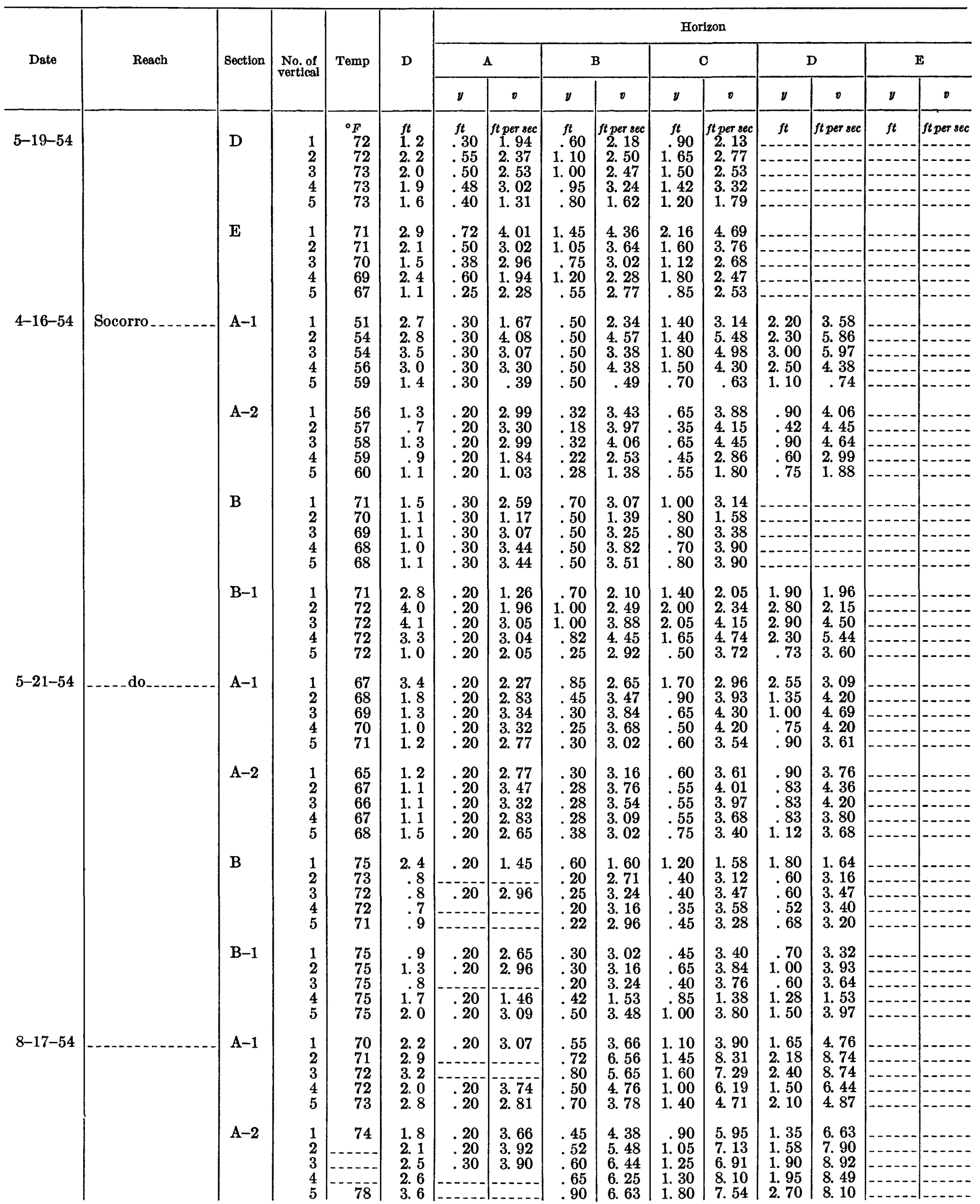


TABLE 1.-Velocity distribution-Con tinued

\begin{tabular}{|c|c|c|c|c|c|c|c|c|c|c|c|c|c|c|c|}
\hline \multirow{3}{*}{ Date } & \multirow{3}{*}{ Reach } & \multirow{3}{*}{ Section } & \multirow{3}{*}{$\begin{array}{l}\text { No. of } \\
\text { vertical }\end{array}$} & \multirow{3}{*}{ Temp } & \multirow{3}{*}{ D } & \multicolumn{10}{|c|}{ Horizon } \\
\hline & & & & & & \multicolumn{2}{|c|}{$\mathbf{A}$} & \multicolumn{2}{|c|}{ B } & \multicolumn{2}{|c|}{0} & \multicolumn{2}{|c|}{$\mathrm{D}$} & \multicolumn{2}{|c|}{$\mathrm{E}$} \\
\hline & & & & & & $y$ & 0 & $y$ & $b$ & $y$ & v & $y$ & $v$ & $y$ & o \\
\hline $7-10-61$ & Bernardo & & $\begin{array}{l}1 \\
2\end{array}$ & ${ }^{\circ} F$ & $\begin{array}{l}f t \\
2.6 \\
2.5\end{array}$ & $\begin{array}{l}f t \\
.30 \\
.30\end{array}$ & $\begin{array}{c}f t \text { per sec } \\
2.92 \\
2.86\end{array}$ & $\begin{array}{l}f t \\
.70 \\
.70\end{array}$ & $\begin{array}{c}\text { ft per sec } \\
3.28 \\
3.43\end{array}$ & $\begin{array}{l}{ }^{f t} \\
\text { 1. } 10 \\
\text { 1. } 20\end{array}$ & $\begin{array}{c}f t \text { per sec } \\
3.80 \\
3.72\end{array}$ & $\begin{array}{c}\stackrel{f t}{ }{ }^{2} \\
\text { 1. } 60 \\
\text { 1. } 70\end{array}$ & $\begin{array}{c}f t \text { per sec } \\
3.97 \\
3.97\end{array}$ & $\begin{array}{l}\stackrel{f t}{2} \\
\text { 2. } \\
10\end{array}$ & $\begin{array}{r}\text { ft per } 8 e \\
\text { 3. } 97 \\
\text { 3. } 97\end{array}$ \\
\hline $19-61$ & _. do & & $\begin{array}{l}1 \\
2\end{array}$ & $\begin{array}{l}74 \\
74\end{array}$ & $\begin{array}{l}\text { 5. } 8 \\
\text { 4. } 8\end{array}$ & $\begin{array}{l}.50 \\
.50\end{array}$ & $\begin{array}{l}\text { 3. } 80 \\
4.45\end{array}$ & $\begin{array}{r}1.00 \\
.80\end{array}$ & $\begin{array}{l}\text { 4. } 25 \\
\text { 4. } 48\end{array}$ & $\begin{array}{l}\text { 2. } 20 \\
\text { 1. } 80\end{array}$ & $\begin{array}{l}4.84 \\
4.69\end{array}$ & $\begin{array}{l}\text { 3. } 40 \\
\text { 2. } 80\end{array}$ & $\begin{array}{l}\text { 5. } 18 \\
\text { 4. } 88\end{array}$ & $\begin{array}{l}\text { 4. } 60 \\
\text { 3. } 80\end{array}$ & $\begin{array}{l}\text { 5. } 18 \\
\text { 5. } 12\end{array}$ \\
\hline
\end{tabular}

TABLE 2.-Suspended-sediment distribution

\begin{tabular}{|c|c|c|c|c|c|c|c|c|c|}
\hline \multirow{2}{*}{ Date } & \multirow{2}{*}{ Reach } & \multirow{2}{*}{ Section } & \multirow{2}{*}{ Horizon } & \multirow{2}{*}{$\begin{array}{c}\text { A verage } \\
\frac{D D-y}{y}\end{array}$} & \multicolumn{5}{|c|}{ Concentration, ppm of indicated sizes } \\
\hline & & & & & $<0.0625$ & $0.0625-0.125$ & $0.125-0.25$ & $0.25-0.50$ & Total \\
\hline $6-2-53$ & Bernalillo_.... & A-2 & $\begin{array}{l}\mathrm{A} \\
\mathrm{B} \\
\mathrm{C} \\
\mathrm{D} \\
\mathbf{E}\end{array}$ & $\begin{array}{r}8.28 \\
2.17 \\
1.07 \\
.50 \\
.13\end{array}$ & $\begin{array}{l}m m \\
1,300 \\
1,310 \\
1,240 \\
1,240 \\
1,150\end{array}$ & $\begin{array}{r}m m \\
726 \\
\mathbf{5 6 9} \\
\mathbf{5 0 0} \\
398 \\
309\end{array}$ & $\begin{array}{r}m m \\
637 \\
396 \\
284 \\
239 \\
168\end{array}$ & $\begin{array}{r}m m \\
207 \\
85 \\
63 \\
58 \\
23 \\
23\end{array}$ & $\begin{array}{l}2,870 \\
2,360 \\
2,090 \\
1,930 \\
1,650\end{array}$ \\
\hline \multirow[t]{4}{*}{$4-53$} & - . . do do . . & A-2 & $\begin{array}{l}\mathrm{A} \\
\mathbf{B} \\
\mathbf{C} \\
\mathrm{D} \\
\mathbf{E}\end{array}$ & $\begin{array}{r}6.78 \\
2.19 \\
.95 \\
.46 \\
.15\end{array}$ & $\begin{array}{r}840 \\
1,070 \\
907 \\
861 \\
837\end{array}$ & $\begin{array}{l}489 \\
381 \\
386 \\
287 \\
291\end{array}$ & $\begin{array}{l}403 \\
156 \\
261 \\
169 \\
169\end{array}$ & $\begin{array}{l}59 \\
16 \\
27 \\
13 \\
33\end{array}$ & $\begin{array}{l}1,790 \\
1,620 \\
1,580 \\
1,330 \\
1,330\end{array}$ \\
\hline & & $\mathbf{A}$ & $\begin{array}{l}\mathrm{A} \\
\mathrm{B} \\
\mathbf{C} \\
\mathrm{D} \\
\mathrm{E}\end{array}$ & $\begin{array}{r}10.54 \\
2.73 \\
1.00 \\
.43 \\
.09\end{array}$ & $\begin{array}{l}802 \\
796 \\
804 \\
704 \\
719\end{array}$ & $\begin{array}{l}656 \\
572 \\
451 \\
368 \\
282\end{array}$ & $\begin{array}{l}821 \\
396 \\
270 \\
159 \\
144\end{array}$ & $\begin{array}{r}80 \\
45 \\
15 \\
9 \\
6\end{array}$ & $\begin{array}{l}2,360 \\
1,810 \\
1,540 \\
1,240 \\
1,150\end{array}$ \\
\hline & & C & $\begin{array}{l}\mathrm{A} \\
\mathbf{B} \\
\mathbf{C} \\
\mathrm{D} \\
\mathbf{E}\end{array}$ & $\begin{array}{r}6.44 \\
\text { 2. } 08 \\
.98 \\
.49 \\
.16\end{array}$ & $\begin{array}{l}895 \\
830 \\
775 \\
734 \\
753\end{array}$ & $\begin{array}{l}355 \\
314 \\
248 \\
248 \\
191\end{array}$ & $\begin{array}{r}334 \\
208 \\
117 \\
124 \\
81\end{array}$ & $\begin{array}{r}76 \\
18 \\
9 \\
15 \\
5\end{array}$ & $\begin{array}{l}1,660 \\
1,370 \\
1,150 \\
1,120 \\
1,030\end{array}$ \\
\hline & & $\mathrm{E}$ & $\begin{array}{l}\mathrm{A} \\
\mathrm{B} \\
\mathrm{C} \\
\mathrm{D} \\
\mathrm{E}\end{array}$ & $\begin{array}{r}5.64 \\
2.03 \\
.97 \\
.46 \\
.18\end{array}$ & $\begin{array}{l}774 \\
827 \\
821 \\
763 \\
675\end{array}$ & $\begin{array}{l}334 \\
222 \\
238 \\
189 \\
156\end{array}$ & $\begin{array}{l}434 \\
291 \\
258 \\
165 \\
120\end{array}$ & $\begin{array}{r}48 \\
40 \\
34 \\
14 \\
6\end{array}$ & $\begin{array}{r}1,590 \\
1,380 \\
1,350 \\
1,130 \\
956\end{array}$ \\
\hline \multirow[t]{3}{*}{$4-13-54$} & $\ldots$ do $\ldots$ & $\mathrm{B}$ & $\begin{array}{l}\mathrm{A} \\
\mathrm{B} \\
\mathrm{C} \\
\mathrm{D}\end{array}$ & $\begin{array}{r}15.6 \\
2.98 \\
1.00 \\
.25\end{array}$ & $\begin{array}{l}3,090 \\
2,920 \\
2,870 \\
2,720\end{array}$ & $\begin{array}{l}988 \\
537 \\
361 \\
270\end{array}$ & $\begin{array}{r}1,250 \\
431 \\
200 \\
105\end{array}$ & $\begin{array}{r}188 \\
27 \\
10 \\
---\end{array}$ & $\begin{array}{l}5,520 \\
3,920 \\
3,440 \\
3,100\end{array}$ \\
\hline & & $\mathbf{C}$ & $\begin{array}{l}\mathrm{A} \\
\mathrm{B} \\
\mathrm{C} \\
\mathrm{D}\end{array}$ & $\begin{array}{r}19.6 \\
2.98 \\
1.00 \\
.25\end{array}$ & $\begin{array}{l}2,890 \\
2,620 \\
2,670 \\
2,720\end{array}$ & $\begin{array}{l}567 \\
344 \\
315 \\
267\end{array}$ & $\begin{array}{l}859 \\
305 \\
272 \\
191\end{array}$ & $\begin{array}{l}44 \\
43 \\
23 \\
10\end{array}$ & $\begin{array}{l}4,360 \\
3,310 \\
3,280 \\
3,180\end{array}$ \\
\hline & & $\mathrm{D}$ & $\begin{array}{l}\mathrm{A} \\
\mathrm{B} \\
\mathbf{C} \\
\mathrm{D}\end{array}$ & $\begin{array}{r}18.0 \\
2.81 \\
.98 \\
.36\end{array}$ & $\begin{array}{l}2,550 \\
2,810 \\
2,730 \\
2,740\end{array}$ & $\begin{array}{l}769 \\
344 \\
241 \\
230\end{array}$ & $\begin{array}{r}1,120 \\
315 \\
178 \\
92\end{array}$ & $\begin{array}{r}330 \\
107 \\
29 \\
3\end{array}$ & $\begin{array}{l}4,930 \\
3,580 \\
3,170 \\
3,070\end{array}$ \\
\hline $4-13-54$ & - ndo do & $\mathbf{E}$ & $\begin{array}{l}\mathrm{A} \\
\mathrm{B} \\
\mathbf{C} \\
\mathrm{D}\end{array}$ & $\begin{aligned} 21 . & 0 \\
3 . & 11 \\
1 . & 17 \\
. & 31\end{aligned}$ & $\begin{array}{l}3,100 \\
2,840 \\
2,770 \\
2,750\end{array}$ & $\begin{array}{l}749 \\
357 \\
304 \\
246\end{array}$ & $\begin{array}{r}1,300 \\
350 \\
240 \\
135\end{array}$ & $\begin{array}{r}604 \\
61 \\
23 \\
13\end{array}$ & $\begin{array}{l}5,810 \\
3,610 \\
3,340 \\
3,150\end{array}$ \\
\hline
\end{tabular}


DISTRIBUTION OF VELOCITY AND SUSPENDED SEDIMENT, MIDDLE RIO GRANDE

TABLE 2.-Suspended-sediment distribution-Continued

\begin{tabular}{|c|c|c|c|c|c|c|c|c|c|}
\hline \multirow{2}{*}{ Date } & \multirow{2}{*}{ Reach } & \multirow{2}{*}{ Section } & \multirow{2}{*}{ Horizon } & \multirow{2}{*}{$\begin{array}{c}\text { A verage } \\
\frac{D-y}{y}\end{array}$} & \multicolumn{5}{|c|}{ Concentration, ppm of indicated sizes } \\
\hline & & & & & $<0.0625$ & $0.0625-0.125$ & $0.125-0.25$ & $0.25-0.50$ & Total \\
\hline \multirow[t]{4}{*}{$5-19-54$} & \multirow[t]{4}{*}{ Bernalillo_. } & B & $\begin{array}{l}\text { A } \\
\mathbf{B} \\
\mathbf{C} \\
\mathrm{D}\end{array}$ & $\begin{array}{r}30.2 \\
2.99 \\
1.00 \\
.33\end{array}$ & $\begin{array}{l}m m \\
2,850 \\
2,880 \\
2,880 \\
2,760\end{array}$ & $\begin{array}{r}m m \\
710 \\
454 \\
476 \\
403\end{array}$ & \begin{tabular}{r}
\multicolumn{1}{l}{$m m$} \\
1,150 \\
431 \\
381 \\
264
\end{tabular} & $\begin{array}{r}m m \\
456 \\
116 \\
76 \\
45\end{array}$ & $\begin{array}{l}5,180 \\
3,880 \\
3,810 \\
3,470\end{array}$ \\
\hline & & $\mathrm{C}$ & $\begin{array}{l}A \\
B \\
C \\
D\end{array}$ & $\begin{array}{r}24.6 \\
3.02 \\
1.00 \\
.33\end{array}$ & $\begin{array}{l}2,490 \\
2,390 \\
2,380 \\
2,300\end{array}$ & $\begin{array}{l}863 \\
482 \\
440 \\
377\end{array}$ & $\begin{array}{r}1,200 \\
302 \\
240 \\
199\end{array}$ & $\begin{array}{r}439 \\
32 \\
18 \\
6\end{array}$ & $\begin{array}{l}4,990 \\
3,210 \\
3,080 \\
2,880\end{array}$ \\
\hline & & $\mathrm{D}$ & $\begin{array}{l}\mathrm{A} \\
\mathrm{B} \\
\mathrm{C} \\
\mathrm{D}\end{array}$ & $\begin{array}{r}\text { 16. } 8 \\
\text { 2. } 99 \\
1.00 \\
.33\end{array}$ & $\begin{array}{l}2,390 \\
2,370 \\
2,270 \\
2,360\end{array}$ & $\begin{array}{l}382 \\
444 \\
323 \\
267\end{array}$ & $\begin{array}{r}348 \\
210 \\
142 \\
95\end{array}$ & $\begin{array}{r}44 \\
21 \\
8 \\
5\end{array}$ & $\begin{array}{l}3,160 \\
3,040 \\
2,740 \\
2,720\end{array}$ \\
\hline & & $\mathrm{E}$ & $\begin{array}{l}\mathrm{A} \\
\mathrm{B} \\
\mathrm{C} \\
\mathrm{D}\end{array}$ & $\begin{aligned} & 19 . 0 \\
& 3 . 12 \\
& 1.00 \\
& .32\end{aligned}$ & $\begin{array}{l}2,900 \\
2,890 \\
2,760 \\
2,760\end{array}$ & $\begin{array}{l}715 \\
388 \\
258 \\
252\end{array}$ & $\begin{array}{r}1,120 \\
237 \\
170 \\
96\end{array}$ & $\begin{array}{r}327 \\
11 \\
3 \\
3\end{array}$ & $\begin{array}{l}5,110 \\
3,530 \\
3,260 \\
3,110\end{array}$ \\
\hline \multirow[t]{4}{*}{$4-16-54$} & \multirow[t]{4}{*}{ Socorro } & $A-1$ & $\begin{array}{l}A \\
B \\
C \\
D\end{array}$ & $\begin{aligned} & 26 . 0 \\
& 4.36 \\
& .97 \\
& .22\end{aligned}$ & $\begin{array}{l}6,490 \\
5,390 \\
5,240 \\
4,840\end{array}$ & $\begin{array}{r}1,620 \\
1,120 \\
641 \\
313\end{array}$ & $\begin{array}{r}2,740 \\
897 \\
408 \\
148\end{array}$ & 154 & $\begin{array}{r}11,000 \\
7,410 \\
6,280 \\
5,300\end{array}$ \\
\hline & & $A-2$ & $\begin{array}{l}\mathrm{A} \\
\mathrm{B} \\
\mathrm{C} \\
\mathrm{D}\end{array}$ & $\begin{array}{r}9.60 \\
3.02 \\
1.00 \\
.50\end{array}$ & $\begin{array}{l}5,890 \\
5,660 \\
5,200 \\
5,180\end{array}$ & $\begin{array}{r}1,310 \\
1,050 \\
512 \\
488\end{array}$ & $\begin{array}{r}1,450 \\
560 \\
176 \\
134\end{array}$ & 17 & $\begin{array}{l}8,680 \\
7,270 \\
5,880 \\
5,810\end{array}$ \\
\hline & & B & $\begin{array}{l}\mathrm{A} \\
\mathrm{B} \\
\mathbf{C} \\
\mathrm{D}\end{array}$ & $\begin{array}{r}10.6 \\
2.87 \\
1.15 \\
.41\end{array}$ & $\begin{array}{l}6,390 \\
6,270 \\
5,740 \\
5,400\end{array}$ & $\begin{array}{r}1,290 \\
755 \\
399 \\
405\end{array}$ & $\begin{array}{r}626 \\
232 \\
203 \\
65\end{array}$ & 42 & $\begin{array}{l}8,350 \\
7,260 \\
6,340 \\
5,870\end{array}$ \\
\hline & & $\mathrm{B}-1$ & $\begin{array}{l}A \\
B \\
C \\
D\end{array}$ & $\begin{array}{r}29.4 \\
3.02 \\
1.00 \\
.42\end{array}$ & $\begin{array}{l}6,660 \\
5,720 \\
5,520 \\
5,580\end{array}$ & $\begin{array}{r}1,850 \\
661 \\
376 \\
326\end{array}$ & $\begin{array}{r}2,460 \\
564 \\
158 \\
109\end{array}$ & $\begin{array}{r}316 \\
14 \\
6 \\
12\end{array}$ & $\begin{array}{r}11,300 \\
6,960 \\
6,060 \\
6,030\end{array}$ \\
\hline \multirow[t]{4}{*}{$5-21-54$} & \multirow[t]{4}{*}{ 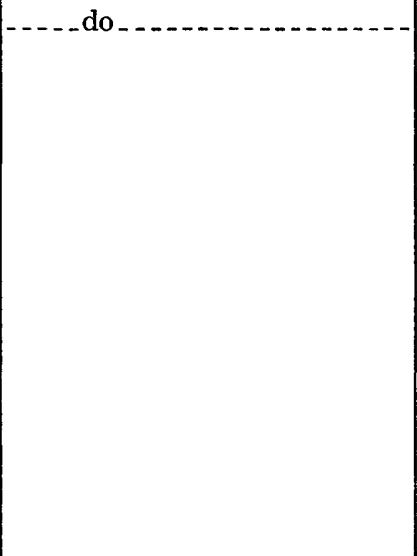 } & $A-1$ & $\begin{array}{l}\mathrm{A} \\
\mathrm{B} \\
\mathrm{C} \\
\mathrm{D}\end{array}$ & $\begin{array}{r}\text { 7. } 70 \\
\text { 3. } 06 \\
\text { 1. } 00 \\
.32\end{array}$ & $\begin{array}{l}14,300 \\
13,900 \\
13,600 \\
13,600\end{array}$ & $\begin{array}{r}2,220 \\
1,050 \\
754 \\
525\end{array}$ & $\begin{array}{r}1,660 \\
431 \\
160 \\
43\end{array}$ & 36 & $\begin{array}{l}18,200 \\
15,400 \\
14,500 \\
14,200\end{array}$ \\
\hline & & $A-2$ & $\begin{array}{l}\mathrm{A} \\
\mathrm{B} \\
\mathrm{C} \\
\mathrm{D}\end{array}$ & $\begin{array}{r}5.00 \\
2.95 \\
1.00 \\
.33\end{array}$ & $\begin{array}{l}15,200 \\
15,000 \\
14,800 \\
14,500\end{array}$ & $\begin{array}{r}2,590 \\
1,570 \\
1,060 \\
544\end{array}$ & $\begin{array}{r}2,230 \\
564 \\
242 \\
91\end{array}$ & 100 & $\begin{array}{l}20,100 \\
17,100 \\
16,100 \\
15,100\end{array}$ \\
\hline & & $\mathbf{B}$ & $\begin{array}{l}\mathrm{A} \\
\mathrm{B} \\
\mathbf{C} \\
\mathrm{D}\end{array}$ & $\begin{array}{r}6.60 \\
3.52 \\
1.00 \\
.33\end{array}$ & $\begin{array}{l}13,500 \\
13,800 \\
13,300 \\
12,900\end{array}$ & $\begin{array}{r}1,000 \\
1,040 \\
649 \\
612\end{array}$ & $\begin{array}{l}465 \\
444 \\
169 \\
109\end{array}$ & & $\begin{array}{l}15,000 \\
15,300 \\
14,100 \\
13,600\end{array}$ \\
\hline & & B-1 & $\begin{array}{l}\mathrm{A} \\
\mathrm{B} \\
\mathrm{C} \\
\mathrm{D}\end{array}$ & $\begin{array}{r}5.70 \\
2.88 \\
1.00 \\
.32\end{array}$ & $\begin{array}{l}13,000 \\
13,300 \\
12,900 \\
12,600\end{array}$ & $\begin{array}{r}1,620 \\
1,120 \\
778 \\
475\end{array}$ & $\begin{array}{r}2,020 \\
680 \\
250 \\
106\end{array}$ & 67 & $\begin{array}{l}16,700 \\
15,100 \\
13,900 \\
13,200\end{array}$ \\
\hline \multirow[t]{2}{*}{$8-17-54$} & \multirow[t]{2}{*}{ 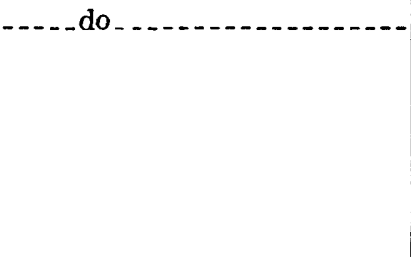 } & $A-1$ & $\begin{array}{l}\mathrm{A} \\
\mathrm{B} \\
\mathrm{C} \\
\mathrm{D}\end{array}$ & $\begin{array}{r}12.6 \\
3.00 \\
1.00 \\
.33\end{array}$ & $\begin{array}{l}109,000 \\
110,000 \\
107,000 \\
105,000\end{array}$ & $\begin{array}{r}13,700 \\
10,800 \\
10,500 \\
8,380\end{array}$ & $\begin{array}{r}18,100 \\
11,200 \\
6,880 \\
4,010\end{array}$ & $\begin{array}{r}5,000 \\
396 \\
250 \\
118\end{array}$ & $\begin{array}{l}147,000 \\
132,000 \\
125,000 \\
118,000\end{array}$ \\
\hline & & $A-2$ & $\begin{array}{l}\mathrm{A} \\
\mathrm{B} \\
\mathbf{C} \\
\mathrm{D}\end{array}$ & $\begin{array}{r}10.8 \\
3.04 \\
1.00 \\
.33\end{array}$ & $\begin{array}{r}100,000 \\
100,000 \\
98,900 \\
99,100\end{array}$ & $\begin{array}{r}15,600 \\
17,700 \\
15,100 \\
8,140\end{array}$ & $\begin{array}{r}38,500 \\
13,600 \\
7,810 \\
2,750\end{array}$ & $\begin{array}{r}4,770 \\
528 \\
122\end{array}$ & $\begin{array}{l}159,000 \\
132,000 \\
122,000 \\
110,000\end{array}$ \\
\hline
\end{tabular}


TABLE 2.-Suspended-sediment distribution-Continued

\begin{tabular}{|c|c|c|c|c|c|c|c|c|c|}
\hline \multirow{2}{*}{ Date } & \multirow{2}{*}{ Reach } & \multirow{2}{*}{ Section } & \multirow{2}{*}{ Horizon } & \multirow{2}{*}{$\begin{array}{c}\text { A verage } \\
\frac{D-y}{y}\end{array}$} & \multicolumn{5}{|c|}{ Concentration, ppm of indicated sizes } \\
\hline & & & & & $<0.0625$ & $0.0625-0.125$ & $0.125-0.25$ & $0.25-0.50$ & Total \\
\hline $7-10-61$ & Bernardo & & $\begin{array}{l}\text { A } \\
\text { B } \\
\text { C } \\
\text { D } \\
\text { E }\end{array}$ & $\begin{array}{r}7.33 \\
3.27 \\
1.08 \\
.47 \\
.19\end{array}$ & $\begin{array}{l}m m \\
66,400 \\
65,600 \\
65,700 \\
64,900 \\
65,200\end{array}$ & $\begin{array}{r}m m \\
475 \\
398 \\
265 \\
261 \\
196\end{array}$ & $\begin{array}{l}m m \\
881 \\
265 \\
199 \\
131 \\
131\end{array}$ & $\begin{array}{c}m m \\
m \\
\end{array}$ & $\begin{array}{l}67,800 \\
66,300 \\
66,200 \\
65,300 \\
65,500\end{array}$ \\
\hline $8-18-61$ & - . . do & & $\begin{array}{l}\text { A } \\
\text { B } \\
\text { C } \\
\text { D }\end{array}$ & $\begin{array}{r}4.20 \\
1.36 \\
.62 \\
.24\end{array}$ & $\begin{array}{l}177,000 \\
177,000 \\
177,000 \\
177,000\end{array}$ & $\begin{array}{l}410 \\
357 \\
391 \\
268\end{array}$ & $\begin{array}{l}374 \\
357 \\
355 \\
250\end{array}$ & $\cdots$ & $\begin{array}{l}178,000 \\
178,000 \\
178,000 \\
178,000\end{array}$ \\
\hline $19-61$ & $\ldots$ do $\ldots$ & & $\begin{array}{l}\text { A } \\
\text { B } \\
\text { C } \\
\text { D } \\
\mathbf{E}\end{array}$ & $\begin{array}{r}9.60 \\
4.90 \\
1.66 \\
.71 \\
.26\end{array}$ & $\begin{array}{l}128,000 \\
127,000 \\
128,000 \\
128,000 \\
125,000\end{array}$ & $\begin{array}{l}1,970 \\
1,870 \\
1,790 \\
1,860 \\
1,850\end{array}$ & $\begin{array}{r}1, \mathbf{5 2 0} \\
1,330 \\
1,320 \\
1, \mathbf{1 3 0} \\
\mathbf{9 5 5}\end{array}$ & - & $\begin{array}{l}132,000 \\
130,000 \\
131,000 \\
131,000 \\
128,000\end{array}$ \\
\hline
\end{tabular}

TABLE 3.-Basic data

\begin{tabular}{|c|c|c|c|c|c|c|c|c|c|c|c|c|c|c|c|c|}
\hline \multirow{3}{*}{ Reach } & \multirow{3}{*}{ Date } & \multirow{3}{*}{ Section } & \multirow{3}{*}{$Q$} & \multirow{3}{*}{$W$} & \multirow{3}{*}{$\bar{D}$} & \multirow{3}{*}{$\bar{V}$} & \multirow{3}{*}{$\begin{array}{c}\text { Ave. } \\
\text { temp. }\end{array}$} & \multirow{3}{*}{ Slope } & \multirow{2}{*}{\multicolumn{5}{|c|}{$\frac{\text { Composition of bed material }}{\text { Percent finer than indicated size }}$}} & \multirow{3}{*}{$d_{36}$} & \multirow{3}{*}{$d_{s 0}$} & \multirow{3}{*}{$d_{06}$} \\
\hline & & & & & & & & & & & & & & & & \\
\hline & & & & & & & & & 0.062 & 0.125 & 0.250 & 0.500 & 1.000 & & & \\
\hline Bernalillo_..- & $\begin{array}{r}6-2-53 \\
4-53\end{array}$ & $\begin{array}{l}\mathrm{A}-2 \\
\mathrm{~A}-2 \\
\mathrm{~A} \\
\mathrm{C} \\
\mathrm{E} \\
\mathrm{B} \\
\mathrm{C} \\
\mathrm{D} \\
\mathrm{E} \\
\mathrm{B} \\
\mathrm{C} \\
\mathrm{D} \\
\mathrm{E}\end{array}$ & $\begin{array}{l}\text { cfs } \\
2,150 \\
2,090 \\
1,970 \\
2,070 \\
1,780 \\
1,200 \\
1,160 \\
1,160 \\
1,200 \\
1,450 \\
1,430 \\
1,410 \\
1,430\end{array}$ & $\begin{array}{r}f t \\
270 \\
270 \\
397 \\
376 \\
268 \\
432 \\
370 \\
399 \\
265 \\
434 \\
383 \\
401 \\
266\end{array}$ & $\begin{array}{l}\text { ft } \\
2.56 \\
2.48 \\
1.69 \\
2.36 \\
2.47 \\
1.42 \\
1.45 \\
1.53 \\
1.98 \\
1.33 \\
1.96 \\
1.50 \\
1.95\end{array}$ & \begin{tabular}{|l} 
ft per sec \\
3.11 \\
3.12 \\
2.94 \\
2.33 \\
2.69 \\
1.96 \\
2.17 \\
1.89 \\
2.30 \\
2.51 \\
1.90 \\
2.35 \\
2.75
\end{tabular} & $\begin{array}{l}\circ F \\
71 \\
62 \\
66 \\
71 \\
70 \\
62 \\
63 \\
63 \\
62 \\
68 \\
73 \\
73 \\
70\end{array}$ & $\begin{array}{r}f t \text { per ft } \\
\mathrm{a} 0.000826 \\
.000826 \\
.000826 \\
.000826 \\
.000826 \\
.000864 \\
.000864 \\
.000864 \\
.000864 \\
.000864 \\
.000864 \\
.000864 \\
.000864\end{array}$ & $\begin{array}{r}m m \\
0.7 \\
.5 \\
1.0 \\
.3 \\
.6 \\
.5 \\
.9 \\
1.2 \\
1.0 \\
1.0 \\
.7 \\
.6 \\
1.0\end{array}$ & $\begin{array}{r}m m \\
4.1 \\
3.7 \\
6.0 \\
1.8 \\
4.5 \\
12.4 \\
6.1 \\
7.5 \\
5.9 \\
5.6 \\
4.3 \\
3.7 \\
5.2\end{array}$ & $\begin{array}{r}m m \\
27.8 \\
34.1 \\
32.9 \\
16.9 \\
43.7 \\
45.7 \\
43.0 \\
40.2 \\
35.5 \\
34.8 \\
30.6 \\
34.5 \\
36.9\end{array}$ & $\begin{array}{l}m m \\
86.6 \\
74.3 \\
89.4 \\
57.8 \\
94.8 \\
96.3 \\
90.4 \\
84.9 \\
80.5 \\
82.4 \\
76.2 \\
81.6 \\
90.4\end{array}$ & $\begin{array}{l}m m \\
97.9 \\
91.0 \\
97.4 \\
87.8 \\
99.0 \\
99.7 \\
97.3 \\
96.3 \\
95.1 \\
94.5 \\
94.5 \\
94.1 \\
98.1\end{array}$ & $\begin{array}{l}m m \\
0.27 \\
.25 \\
.25 \\
.35 \\
.23 \\
.21 \\
.35 \\
.23 \\
.25 \\
.25 \\
.26 \\
.25 \\
.25\end{array}$ & $\begin{array}{c}m m \\
0.32 \\
.33 \\
.30 \\
.42 \\
.26 \\
.26 \\
.37 \\
.29 \\
.31 \\
.31 \\
.27 \\
.31 \\
.30\end{array}$ & $\begin{array}{c}m m \\
0.37 \\
.42 \\
.35 \\
.60 \\
.31 \\
.30 \\
.56 \\
.35 \\
.38 \\
.38 \\
.41 \\
.38 \\
.35\end{array}$ \\
\hline Socorro_._. & $\begin{array}{r}5-21-54 \\
\text { b } 8-17-54\end{array}$ & $\begin{array}{l}\text { A-1 } \\
\text { A-2 } \\
\text { B } \\
\text { B-1 } \\
\text { A-1 } \\
\text { A-2 } \\
\text { B } \\
\text { B-1 } \\
\text { A-1 } \\
\text { A-2 }\end{array}$ & $\begin{array}{r}697 \\
697 \\
697 \\
697 \\
891 \\
900 \\
874 \\
840 \\
3,600 \\
3,550\end{array}$ & $\begin{array}{l}175 \\
241 \\
447 \\
202 \\
222 \\
233 \\
327 \\
368 \\
258 \\
234\end{array}$ & $\begin{array}{l}1.53 \\
1.00 \\
.66 \\
1.44 \\
1.16 \\
1.20 \\
1.07 \\
.91 \\
2.30 \\
2.38\end{array}$ & $\begin{array}{l}2.60 \\
2.90 \\
2.36 \\
2.40 \\
3.45 \\
3.21 \\
2.50 \\
2.51 \\
6.07 \\
\text { 6. } 37\end{array}$ & $\begin{array}{l}55 \\
58 \\
69 \\
72 \\
69 \\
67 \\
73 \\
75 \\
72 \\
76\end{array}$ & $\begin{array}{l}.000758 \\
.000758 \\
.000980 \\
.000980 \\
.000844 \\
.000844 \\
.00100 \\
.00100 \\
.000855 \\
.000855\end{array}$ & $\begin{array}{l}3.6 \\
4.2 \\
5.4 \\
1.7 \\
3.2 \\
4.7 \\
8.8 \\
2.3 \\
5.3 \\
2.6\end{array}$ & $\begin{aligned} 16.7 \\
19.9 \\
25.1 \\
10.0 \\
16.6 \\
21.4 \\
29.0 \\
11.3 \\
12.6 \\
7.7\end{aligned}$ & $\begin{array}{l}68.1 \\
87.4 \\
85.7 \\
67.2 \\
76.5 \\
88.0 \\
89.8 \\
79.2 \\
53.4 \\
48.3\end{array}$ & $\begin{array}{l}83.2 \\
99.3 \\
98.7 \\
94.5 \\
96.5 \\
99.2 \\
99.2 \\
98.4 \\
94.4 \\
97.7\end{array}$ & $\begin{array}{l}84.2 \\
99.9 \\
99.4 \\
98.2 \\
99.1 \\
99.8 \\
99.6 \\
99.0 \\
99.4 \\
99.3\end{array}$ & $\begin{array}{l}.15 \\
.15 \\
.14 \\
.18 \\
.16 \\
.14 \\
.13 \\
.16 \\
.19 \\
.21\end{array}$ & $\begin{array}{l}.17 \\
.17 \\
.16 \\
.21 \\
.19 \\
.16 \\
.15 \\
.19 \\
.24 \\
.25\end{array}$ & $\begin{array}{l}.19 \\
.19 \\
.19 \\
.24 \\
.22 \\
.19 \\
.18 \\
.21 \\
.29 \\
.29\end{array}$ \\
\hline Bernardo & $\begin{array}{r}7-10-61 \\
8-18-61 \\
19-61\end{array}$ & & $\begin{array}{r}403 \\
636 \\
2,380\end{array}$ & $\begin{array}{r}82.0 \\
90.0 \\
119\end{array}$ & $\begin{array}{l}\text { 1. } 71 \\
2.08 \\
\text { 4. } 47\end{array}$ & $\begin{array}{l}\text { 2. } 88 \\
\text { 3. } 40 \\
\text { 4. } 46\end{array}$ & $\begin{array}{l}72 \\
75 \\
74\end{array}$ & $\begin{array}{l}.000385 \\
.00049 \\
.00024\end{array}$ & $\begin{array}{l}53.3 \\
84.8 \\
65.6\end{array}$ & $\begin{array}{l}70.8 \\
88.7 \\
69.3\end{array}$ & $\begin{array}{l}92.3 \\
96.9 \\
81.1\end{array} \mid$ & $\begin{array}{l}99.8 \\
99.7 \\
98.2\end{array}$ & $\begin{array}{l}100.0 \\
100.0 \\
100.0\end{array}$ & .0092 & .048 & .10 \\
\hline
\end{tabular}

- Estimated on basis of adjoining values.

b Flow on this day is from Rio Puerco. 
DISTRIBUTION OF VELOCITY AND SUSPENDED SEDIMENT, MIDDLE RIO GRANDE

TABLE 4.-Computed parameters

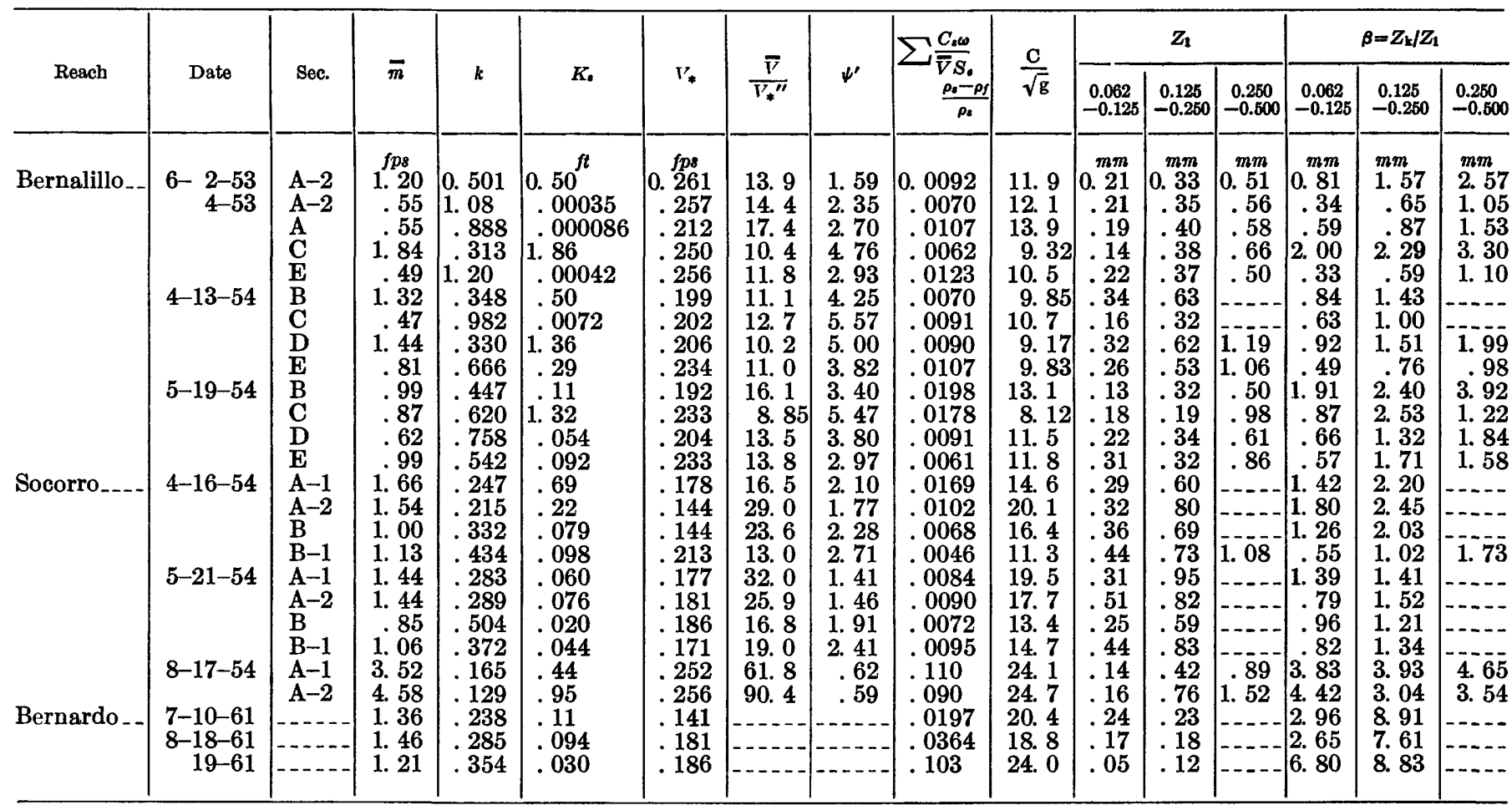

TABLE 5.-Basic data and computed parameters for the average of 13 cross sections through a 16,000-foot reach, Rio Grande near Bernalillo, N. Mex.

\begin{tabular}{|c|c|c|c|c|c|c|c|c|c|c|c|}
\hline \multirow{2}{*}{ Date } & \multirow{2}{*}{$Q$} & \multirow{2}{*}{$P_{\|}$} & \multirow{2}{*}{$\boldsymbol{R}$} & \multirow{2}{*}{$b$} & \multirow{2}{*}{$V$} & \multirow{2}{*}{$T$} & \multirow{2}{*}{$\boldsymbol{S}$} & \multicolumn{2}{|c|}{ Bed material (mm) } & \multirow{2}{*}{$\psi^{\prime}$} & \multirow{2}{*}{$v / v u$} \\
\hline & & & & & & & & $d_{35}$ & $d_{00}$ & & \\
\hline $\begin{array}{r}1958 \\
4-25 \\
5-12 \\
6-17 \\
20 \\
26 \\
7-24\end{array}$ & $\begin{array}{l}c f_{8} \\
2,820 \\
6,440 \\
6,120 \\
4,775 \\
2,800 \\
2,030\end{array}$ & $\begin{array}{c}f t \\
454.0 \\
485.2 \\
477.3 \\
429.5 \\
384.3 \\
424.4\end{array}$ & $\begin{array}{l}\text { ft } \\
\text { 1. } 63 \\
\text { 2. } 35 \\
2.41 \\
\text { 2. } 20 \\
\text { 2. } 04 \\
1.95\end{array}$ & $\begin{array}{l}f t \\
452 \\
477 \\
475 \\
427 \\
382 \\
422\end{array}$ & $\begin{array}{r}\text { ft per sec } \\
\text { 3. } 83 \\
5.65 \\
\text { 5. } 32 \\
\text { 5. } 09 \\
\text { 3. } 57 \\
\text { 2. } 46\end{array}$ & $\begin{array}{r}{ }^{\circ} F \\
61 \\
64 \\
72 \\
72 \\
70 \\
78\end{array}$ & $\begin{array}{r}f t \text { per } f t \\
0.00090 \\
.00086 \\
.00086 \\
.00086 \\
.00085 \\
.00088\end{array}$ & $\begin{array}{r}0.230 \\
.278 \\
.270 \\
.290 \\
.260 \\
.283\end{array}$ & $\begin{array}{r}0.330 \\
.406 \\
.385 \\
.420 \\
.375 \\
.405\end{array}$ & $\begin{array}{l}1.61 \\
.96 \\
\text { 1. } 04 \\
1.16 \\
1.99 \\
\text { 3. } 94\end{array}$ & $\begin{array}{l}25.7 \\
47.1 \\
36.4 \\
38.9 \\
19.5 \\
11.9\end{array}$ \\
\hline
\end{tabular}




\section{REFERENCES CITED}

Anderson, A. G., 1942, Distribution of suspended sediment in a natural stream: Am. Geophys. Union Trans. 23d Ann. Mtg., pt. 2 , p. $678-683$.

Carey, W. C., and Keller, M. D., 1957, Systematic changes in the beds of alluvial rivers: Am. Soc. Civil Engineers Jour., v. 83 , no. HY 4 .

Chien, Ning, 1954, The present status of research on sediment transport: Am. Soc. Civil Engineers Proc., separate no. $565,33 \mathrm{p}$.

Colby, B. R. and Hembree, C. H., 1955, Computations of total sediment discharge, Niobrara River near Cody, Nebraska: U.S. Geol. Survey Water-Supply Paper 1357, $187 \mathrm{p}$.

Culbertson, J. K., and Dawdy, D. R., 1963, A study of fluvial characteristics and hydraulic variables, middle Rio Grande, New Mexico: U.S. Geol. Survey Water-Supply Paper 1498-F.

Culbertson, J. K., and Nordin, C. F., 1960, Discussion of discharge formula for straight alluvial channels: Am. Soc. Civil Engineers Jour., v. 86, no. HY 6.

Dawdy, D. R., 1961, Depth-discharge relations of alluvial streams-discontinuous rating curves: U.S. Geol. Survey Water-Supply Paper 1498-C, 16 p.

Einstein, H. A., 1950, The bed-load function for sediment transportation in open channel flows: U.S. Dept. Agriculture Tech. Bull. 1026, 70 p. [1951].

Einstein, H. A., and Barbarossa, N. L., 1952, River channel roughness: Am. Soc. Civil Engineers Trans. paper 2528, v. 117, p. 1121-1132.

Einstein, H. A., and Chien, Ning, 1954, Second approximation to the solution of the suspended load theory: California Univ., Inst. Engineering Research, Missouri River Div. sediment ser. $3,30 \mathrm{p}$.

- 1955, Effects of heavy sediment concentration near the bed on velocity and sediment distribution: California Univ., Inst. Engineering Research, Missouri River Div. sediment ser. $8,45 \mathrm{p}$.

Ismail, H. M., 1951, Turbulent transfer mechanism and suspended sediment in closed channels: Am. Soc. Civil Engineers Proc., separate no. 56, 26 p.
Keulegan, G. H., 1938, Laws of turbulent flow in open channels: U.S. Natl. Bur. Standards, Jour. Research, v. 21, no. 6, p. 707-741.

Liu, H. K., and Hwang, S. Y., 1959, Discharge formula for straight alluvial channels: Am. Soc. Civil Engineers Journ., v. 85, no. HY 11.

O'Brien, M. P., 1933, Review of the theory of turbulent flow and its relation to sediment transportation: Am. Geophys. Union Trans., v. 14, p. 487-491.

Richardson, E. V., Simons, D. B., and Posakony, G. J., 1961, Sonic depth sounder for laboratory and field use: U.S. Geol. Survey Circ. 450, 7 p.

Rouse, H., 1937, Modern conceptions of the mechanics of fluid turbulence: Am. Soc. Civil Engineers Trans., paper 1965, v. 102 , p. $463-543$.

Sayre, W. W., and Albertson, M. L., 1961, Roughness spacing in rigid open channels: Am. Soc. Civil Engineers Jour., v. 87, no. HY 3.

Simons, D. B., and Richardson, E. V., 1961, Forms of bed roughness in alluvial channels: Am. Soc. Civil Engineers Jour., v. 87, no. HY 3.

Simons, D. B., Richardson, E. V., and Haushild, W. L., 1963, The effects of fine sediment on the mechanics of flow: U.S. Geol. Survey Water-Supply Paper 1498-G.

U.S. Inter-Agency Report No. 4, 1941, Methods of analyzing sediment samples: St. Paul, Minn., U.S. Dept. Army.

U.S. Inter-Agency Report No. 12, 1957, Measurement and analysis of sediment loads in streams: Washington, U.S. Govt. Printing Office.

Vanoni, V. A., 1946, Transportation of suspended sediment by water: Am. Soc. Civil Engineers Trans., paper 2267, v. 111, p. 67-102.

Vanoni, V. A., and Brooks, N. H., 1957, Laboratory studies of the roughness and suspended load of alluvial streams: California Inst. Technology, sediment lab., rept. E-68, 99 p.

Vanoni, V. A., Brooks, N. H., and Kennedy, J. F., 1961, Lecture notes on sediment transportation and channel stability: California Inst. Technology Rept. KH-R-1. 